\title{
Systematic Review \\ Universal School Meals and Associations with Student Participation, Attendance, Academic Performance, Diet Quality, Food Security, and Body Mass Index: A Systematic Review
}

\author{
Juliana F. W. Cohen 1,2,*, Amelie A. Hecht ${ }^{3}$, Gabriella M. McLoughlin ${ }^{4,5}$ (D) Lindsey Turner $^{6}(\mathbb{D}$ \\ and Marlene B. Schwartz ${ }^{7}$ (D) \\ 1 Department of Nutrition and Public Health, Merrimack College, 315 Turnpike Street, \\ North Andover, MA 01845, USA \\ 2 Department of Nutrition, Harvard T.H. Chan School of Public Health, 677 Huntington Ave, \\ Boston, MA 02115, USA \\ 3 Institute for Research on Poverty, University of Wisconsin-Madison, 1180 Observatory Drive, \\ Madison, WI 53706, USA; aahecht2@wisc.edu \\ 4 Implementation Science Center for Cancer Control and Prevention Research Center, Brown School, \\ Washington University in St. Louis, St. Louis, MO 63130, USA; gmcloughlin@wustl.edu \\ 5 Division of Public Health Sciences, Department of Surgery, Washington University School of Medicine, \\ Washington University in St. Louis, St. Louis, MO 63130, USA \\ 6 College of Education, Boise State University, 1910 University Drive, Boise, ID 83725-1742, USA; \\ lindseyturner1@boisestate.edu \\ Citation: Cohen, J.F.W.; Hecht, A.A.; \\ McLoughlin, G.M.; Turner, L.; \\ Schwartz, M.B. Universal School \\ 7 Rudd Center for Food Policy and Obesity, Department of Human Development and Family Sciences, \\ University of Connecticut, 1 Constitution Plaza, Suite 600, Hartford, CT 06103, USA; \\ marlene.schwartz@uconn.edu \\ * Correspondence: cohenj@merrimack.edu; Tel.: +1-978-837-5456
} Meals and Associations with Student Participation, Attendance, Academic Performance, Diet Quality, Food Security, and Body Mass Index: A Systematic Review. Nutrients 2021, 13, 911. https://doi.org/10.3390/ nu13030911

Academic Editor:

Gregorio Varela-Moreiras

Received: 3 February 2021

Accepted: 8 March 2021

Published: 11 March 2021

Publisher's Note: MDPI stays neutral with regard to jurisdictional claims in published maps and institutional affiliations.

Copyright: (c) 2021 by the authors. Licensee MDPI, Basel, Switzerland. This article is an open access article distributed under the terms and conditions of the Creative Commons Attribution (CC BY) license (https:// creativecommons.org/licenses/by/ $4.0 /)$.
Abstract: The school environment plays an important role in children's diets and overall health, and policies for universal free school meals have the potential to contribute to positive child health outcomes. This systematic review evaluates studies examining the association between universal free school meals and students' school meal participation rates, diets, attendance, academic performance, and Body Mass Index (BMI), as well as school finances. The search was conducted in accordance with the Preferred Reporting Items for Systematic Review and Meta-Analyses (PRISMA). A search for studies published in economically developed countries published through December 2020 was performed in PubMed, Education Resources Information Center (ERIC), Thomson Reuters' Web of Science, and Academic Search Ultimate, followed by examining the references in the resultant literature. A total of 47 studies were identified and the Newcastle-Ottawa Scale (NOS) was applied to assess bias. Nearly all studies examining universal free school meals found positive associations with school meal participation. Most studies examining universal free school meals that included free lunch found positive associations with diet quality, food security, and academic performance; however, the findings of studies examining only universal free breakfast were mixed. Research findings were similarly mixed when examining attendance as an outcome. Concerns about adverse outcomes on student BMI were not supported by the literature; in fact, several studies detected a potentially protective effect of universal free school meals on BMI. Research examining the impact of universal free meals on school finances was limited, but suggest that lower-income school districts in the U.S. may have positive financial outcomes from participation in universal free school meal provisions. Additionally, providing free meals to students may be associated with improved household incomes, particularly among lower-income families with children. Further research is needed to examine the financial implications of universal free meals for both school districts and families. Overall, universal free school meals may have multiple benefits for students and countries should consider universal free school meal provisions with strong nutrition guidelines. (PROSPERO registration: CRD42020221782). 
Keywords: universal school meals; nutrition; community eligibility provision; breakfast; lunch; attendance; academic performance; BMI

\section{Introduction}

Globally, schools are recognized as an important setting to promote healthy behaviors, as children typically spend a substantial amount of their waking hours at school [1-3]. As children's eating preferences often persist into adulthood, schools can provide meaningful opportunities to promote and establish healthier diets through access to nutritious foods, including breakfast and lunch [1,4-7]. Among countries with developed economies, school meals are a common feature of national safety net programs and typically provide students with breakfast and/or lunch with a focus on improving diet quality, particularly among low-income populations [1]. Many countries have nutrition standards for school meals, which can have important short- and long-term health implications for children, including promoting optimal growth and cognitive development and reducing the risk of food insecurity and obesity [8-18]. School meal programs are commonly means-tested (e.g., based on family income, eligibility for the Supplemental Nutrition Assistance Program [SNAP], etc.), whereby access to subsidized free or reduced-price meals are available to lower-income students. However, policies that support universal free school meals (i.e., meals provided at no cost to all children who wish to participate) are gaining attention as a strategy to reduce stigma and diet-related disparities among lower-income students, promote children's nutrition more broadly (school meals are often healthier than meals brought from home), and potentially lower administrative costs for schools [19-28].

Despite the potential benefits of universal free school meals, they are currently only available in a small number of countries. Beginning in 1943, Finland was the first country to offer universal free school meals, and Sweden implemented them two years later in 1945 [29,30]. More recently, Estonia began providing free school meals to all students in 2002, and South Korea implemented a universal free school meal program in 2011 [11,31]. Additionally, England implemented the Universal Infant Free School Meals (UIFSM) policy for state-funded schools in 2014 and Scotland introduced a similar policy in 2015, both of which only apply to children in their first three years of primary school (children ages 4-7 years at the beginning of the school year) [10,32]. Japan's school meal program, which was first implemented in 1947, is universal but not free; participation in the school meal program is mandatory, and low-income families receive financial support for school meals from the local and/or national government [33,34].

In the United States, there have been multiple provisions supported by the USDA that have enabled high-poverty schools to provide universal free school breakfast and/or lunch. These include: Provision 1, Provision 2, Provision 3, and most recently, the Community Eligibility Provision (CEP) which was introduced as part of the Healthy Hunger-Free Kids Act of 2010 and became available to eligible schools nationwide in 2014 (see Supplemental Table S1 for a summary of school meal provisions in the United States) $[8,35]$. To be eligible to opt into CEP, $\geq 40 \%$ of students in a district or school must be from low-income households, which is determined using existing administrative data (e.g., participation in SNAP). However, in the 2019-2020 school year, only about $69 \%$ of eligible schools in the U.S. were participating in CEP, in part due to concerns about insufficient reimbursement from the federal government [36,37].

While proponents of universal free school meals cite numerous benefits, including higher school meal participation rates and improved student diet quality, academic performance, and attendance, concerns have also been raised about the potential detrimental impact on students' body mass index (BMI) and/or school finances [38,39]. To date, the research examining universal free school meals has not been systematically evaluated. A commentary by Hecht and colleagues, which included a non-systematic review of CEP in the United States, concluded that there was growing evidence of an association with 
positive health and academic benefits for children, but that more research was needed [40]. A better understanding of how universal free school meals impact students and schools can help inform school meal policies globally. Therefore, the aim of this study was to systematically review the international evidence regarding the impact of universal free school meals on students' school meal participation rates, diets, attendance, academic performance, and body mass index (BMI), and as well as school finances.

\section{Materials and Methods}

This review was conducted according to the Preferred Reporting Items for Systematic Reviews and Meta-Analysis (PRISMA) guidelines [41]. The protocol was registered with the PROSPERO International Prospective Register of Systematic Review prior to data extraction (protocol registration number: CRD42020221782) [42].

\subsection{Data Sources and Search Strategies}

Four online databases were used: PubMed, Education Resources Information Center (ERIC), Thomson Reuters' Web of Science, and Academic Search Ultimate. The search strategy was comprised of combinations of the following keywords (adapted for each database): school, universal, free, community eligibility, provision, reimbursement, access, poverty, hunger, meal, breakfast, lunch. Articles in English published since the start of the literature through December 2020 were reviewed. To identify additional potentially relevant studies, a search of the reference lists of these articles as well as a review of all articles citing the resultant literature (using Google Scholar) was performed.

\subsection{Study Selection}

Eligible studies were quantitative research articles evaluating universal free school meals and school meal participation rates, academic performance, attendance, Body Mass Index (BMI), diet quality, food insecurity, and/or school finances. Our inclusion criteria were English, peer-reviewed publications or official government reports within countries with developed economies (i.e., members of the Organization for Economic Co-Operation and Development [OECD]) [43], and conducted in primary (i.e., elementary) and secondary (i.e., middle, and/or high) schools during the academic year (terminology throughout reflects how grade levels are referred to within each country). Studies from Japan examining universal school meals (mandatory for all students but not free) were also included due to the similar nature of the school meal program compared with universal free school meal programs and thus research findings were considered relevant and informative. The following types of articles were excluded: non-English articles; qualitative research; articles that did not examine universal free school breakfast or lunch (e.g., snacks, milk programs, or afterschool programs); initiatives that occurred outside of the school year (i.e., holiday or summer vacations); studies conducted in non-OECD countries; and articles that only compared across different universal free school meal models (i.e., universal free breakfast offered in the cafeteria versus universal free breakfast provided in the classroom). Two independent reviewers conducted the searches and screened titles and abstracts, and the lead author (JFWC) screened full texts. Articles with unclear eligibility were reviewed by the research team. A total of 47 studies that met the inclusion criteria were identified and included in this paper $(n=25$ studies conducted in the U.S. and $n=22$ studies conducted in other OECD countries). Due to the heterogeneity of the study designs and outcome measures of the included studies, the data could not be combined to reanalyze as metaanalyses. Therefore, a qualitative narrative review was used to synthesize the results of the included studies.

\subsection{Quality Assessment}

Assessment of study quality and biases were based on adapted Newcastle-Ottawa Scales (NOS) for cross-sectional and cohort studies, which are commonly used to assess nonrandomized research [44-46]. Each study was assessed by two authors using the following 
criteria: selection, comparability, and outcome. Quality assessments were interpreted based on the following categories: very high risk of bias (0-3 points), high risk of bias (4-6 points), and low risk of bias ( $\geq 7$ points) [47]. Quality Assessments are presented in Supplemental Table S2 (cross-sectional studies) and Supplemental Table S3 (cohort and quasi-experimental studies).

\section{Results}

The original search of the four databases (PubMed, ERIC, Thomson Reuters' Web of Science, and Academic Search Ultimate) identified a total of 9083 articles. After removing duplicates, 4604 articles remained. The primary screening excluded 4122 records. The full text of the remaining 156 publications were assessed in detail, and 121 articles were excluded. The primary reasons for exclusion in this step concerned the study objectives (i.e., did not aim to evaluate universal free school meals or only compared universal free school meal models), publication type (i.e., grey literature), and the location where the study was conducted (i.e., non-OECD countries). Five additional articles were identified from references or publications citing the referent literature. Therefore, a total of 47 articles were included in this review (Figure 1). As seen in Supplemental Tables S2 and S3, quality scores for the included articles ranged from 3 (very high risk of bias) to 10 (low risk of bias). Over half of the included studies $(n=26)$ were classified as having a low risk of bias while $n=12$ articles had high risk and $n=10$ articles had very high risk (one study had both high and low risk of bias for differing outcomes assessed). Research conducted in the U.S. is presented separately from other OECD countries in each section of the review due to the large number of studies and the unique nature of universal free school meal provisions in the U.S. (i.e., universal free school meals are primarily available only in lower-income schools).

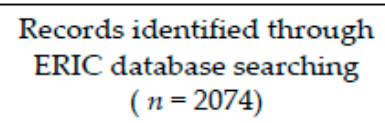
Records identified through Thomson Reuters' Web of Science database searching $(n=1730)$

Records identified through Academic Search Ultimate database searching $(n=2166)$

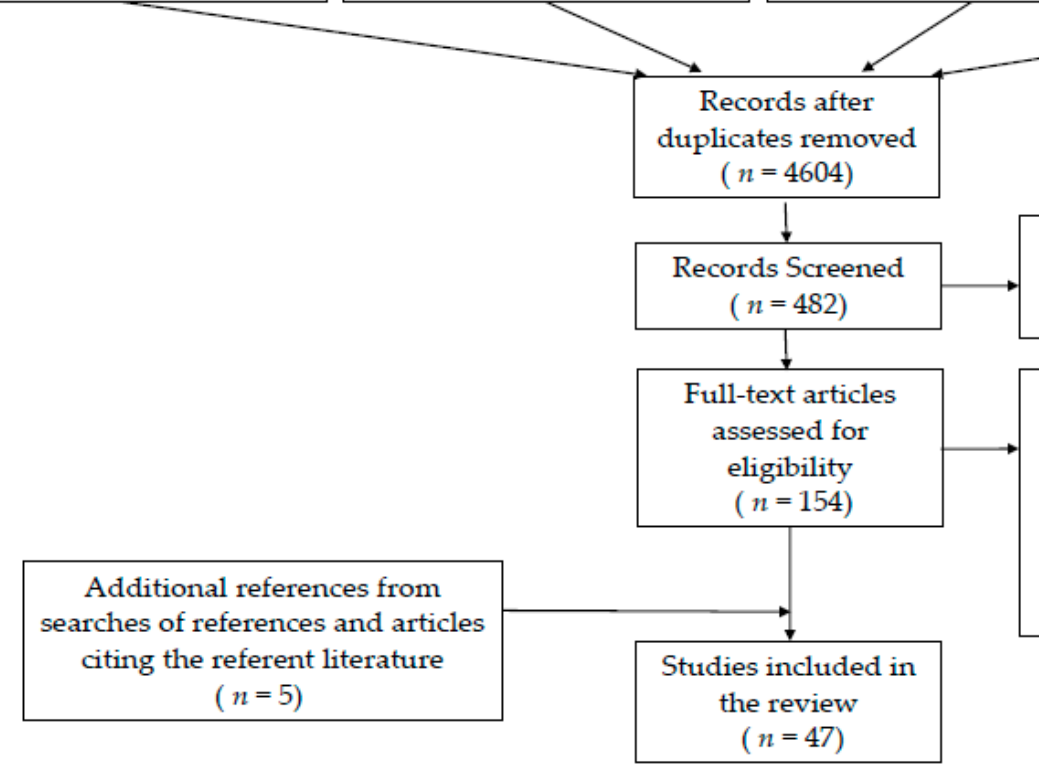

Records excluded after primary screening of titles/abstracts $(n=4122)$

Full-text articles excluded $(n=112)$ :

-Did not match aim of review $(n=65)$

-Not peer-reviewed/government report $(n=34)$;

-Non-OECD country $(n=18)$;

-Studies that only compared universal school meal models $(n=6)$;

Figure 1. Flow chart for systematic review.

\subsection{School Meal Participation}

A primary goal of universal free school meals is to increase school meal participation. Of the 11 peer-reviewed publications and four government reports conducted in the U.S. 
that examined school meal participation as an outcome ( $n=15$ studies; Table 1$), 14$ found a positive association between universal free school meals and National School Lunch Program (NSLP) or School Breakfast Program (SBP) participation and one found mixed results. One peer-reviewed study and two government reports examining universal free school meals in the United Kingdom (UK) also found positive associations with school meal participation (Table 2). Among the studies conducted using methodology with a low risk of bias, all 11 found positive associations between universal free school meals and school meal participation rates.

In the United States, several studies have examined the impact of universal free SBP and program participation. In a study conducted by Leos-Ubel et al. in New York City among elementary and middle school students, access to universal free breakfast was positively associated with SBP participation, with rates varying by student socioeconomic status (SES) [48]. Among students with the lowest household income levels who were already eligible for free school meals, there was an increase in participation by $5 \%(p<0.05)$. Among students previously eligible for reduced-price meals, there was a $21 \%$ increase in SBP participation $(p<0.01)$, and among students eligible for full- price meals previously, there was a $36 \%$ increase in participation $(p<0.01)$. Similar results were observed in a study conducted by Ribar and colleagues in a school district in North Carolina where three elementary schools removed universal free breakfast while one school introduced it [49]. Overall, universal free breakfast was associated with 16.4\% higher rates of SBP participation $(p<0.05)$, with the greatest increase in participation rates among students from higher-income households who were not previously eligible for free or reduced-price meals $(27.5 \% ; p<0.05)$. Nearly identical results were observed in a government report examining the pilot of universal free breakfast in six school districts in six states, with schools within each district randomly assigned to universal free breakfast or control (means-tested based on eligibility for free or reduced-price meals); after one year, universal free breakfast was associated with a 16 percentage point increase in participation $(p=0.01)$, again, with the largest increases observed among students not previously eligible for free or reduced-price meals [50]. In a second government report examining the extended impact of this pilot program, the increases in participation were maintained over three years [51]. Another study conducted by Soldavini and associates in North Carolina elementary, middle, and high schools found that providing universal free breakfasts was positively associated with significantly greater odds of breakfast participation at all grade levels, with the exception of high school students who were previously eligible for free or reduced-price meals [52]. A third study by Wahlstrom et al. examining six elementary schools in Minnesota also observed high SBP participation rates among schools with universal free breakfast, although no statistical analyses were conducted and this study was assessed to have a very high risk of bias [22]. In a cross-sectional study conducted by Khan and colleagues in a Vermont middle school serving universal free breakfast, foodinsecure students were significantly less likely to eat breakfast at home compared with food-secure students, and nearly all (91.3\%) of the food-insecure students reported eating free breakfast at school [53]. However, a cross-sectional study in Philadelphia, Pennsylvania conducted by Dykstra et al. found that students participated in the free SBP only 31\% of the time (however, changes in participation rates were not measured) [54]. Although there were significantly higher participation rates among minority students compared with their white peers, there were no differences in participation by eligibility for free or reduced-price meals or by food-insecurity levels.

Several studies have also examined universal free school meal provisions prior to the implementation of CEP in the U.S. One study in Texas conducted by Rivas examining a school district that implemented Provision 2 observed a 16\% increase in overall school meal participation rates (although this was not analyzed for statistically significant differences and the study was considered to have a very high risk of bias) [55]. Similarly, in a study conducted by Schwartz et al. among middle schools in New York City, Provision 2 was positively associated with NSLP participation, with differences observed by student SES; 
on average there was an $11 \%$ increase in NSLP participation among students not previously eligible for school meals $(p<0.05)$ and a $5.4 \%$ increase among students from lower-income households $(p<0.01)$ [39]. A government report examining a no-fee school meal pilot program in several states found an increase in lunch participation by approximately 10 percentage points (although this study was deemed to have a very high risk of bias) [56]. Another government report evaluating an initiative to eliminate reduced-price fees for school meals observed similar changes, with an 11\% increase in lunch participation and $9 \%$ increase in breakfast participation among students previously eligible for reduced-price meals (and this study also was assessed to have a very high risk of bias) [57].

The CEP was introduced in 2010, and several studies tested its impact using pre-post designs. Pokorney et al. examined all CEP schools $(n=654)$ before and after implementation compared with eligible non-CEP schools (i.e., schools that chose not to participate in CEP but met the eligibility criteria $[n=1221]$ ) in Pennsylvania and found that on average CEP was associated with an $8 \%$ increase in school lunch participation [58]. In sub-analyses examining participation by student SES, NSLP participation rates were higher among students not previously eligible for free or reduced-price meals, but slightly lower among lower-income students in CEP schools compared with non-CEP schools. Turner and colleagues also examined the introduction of CEP, as well as the use of Provisions 1, 2, and 3 in public schools in California, and found that universal free school meals were associated with a 5.8 percentage point increase in NSLP participation and 3.5 percentage point increase in SBP participation [59]. Lastly, Tan et al. used national data from K-8 schools to address this question and found that CEP was associated with an $11.7 \%$ higher likelihood of participating in the NSLP among near-cutoff students (i.e., students who were near the cutoff and had uncertain eligibility for free or reduced-price meals [ $p=0.023]$ ) and a 19\% higher likelihood of participation among students previously eligible for full-price meals $(p<0.001)$ [60]. CEP was also associated with a 19.6\% higher likelihood of participation in the SBP among students previously eligible for full-price meals in this study $(p<0.05)$.

Among research conducted in the UK, a government report examining the pilot of Universal Infant Free School Meals (UIFSM) in England among primary school students in three local authorities found that universal free school meals were associated with approximately a 30\% increase in the percent of students taking a school lunch at least once a week (i.e., roughly $90 \%$ of students had a school lunch at least once week in schools with universal free school meals compared with $60 \%$ of students in matched control schools) [61]. The greatest increases in participation were among students who were not previously eligible for school meals. Similarly, in another government report examining universal free school meals in Scotland, school lunch participation increased by 22 percentage points (from 53\% to 75\%), with the greatest increases among students not previously registered for free school meals (an increase of 28 percentage points) [62]. Another study conducted in primary schools in Scotland examining universal free school meals also found the greatest increases in lunch participation were among students not previously eligible for free school meals (14.4 percentage point increase [ $p<0.001])$ [63].

To summarize, there is a large literature examining the relationship between offering universal free meals and student participation. Overall, the findings consistently show that student participation in school meal programs increases when meals are provided at no costs. Further, the increase in participation tends to be largest among students who previously did not qualify for free or reduced-price meals.

\subsection{Diet Quality and Food Insecurity}

Another priority of universal free school meals is to improve the nutritional quality of children's diets and reduce food insecurity. In the presence of strong nutrition standards, school meals may improve children's diets directly by providing healthy foods (i.e., fruits, vegetables, whole grains, etc.) [23-26,28,64]. There may be indirect benefits as well; prior research has found that healthy school meal consumption is associated with decreased intake of less healthy foods outside of school, potentially attributable to increased satiety 
from nutrient dense, high fiber school meals [65]. Additionally, when school meals are provided at no cost, families are able to save those funds and increase their purchasing power for other foods, further reducing food insecurity. Of the six peer-reviewed publications and one government report conducted in the U.S. that examined diet-related outcomes $(n=7$ studies [Table 1]), two found a positive association between universal free school meals and dietary quality and two found a positive association with food security. Three studies examined only universal free breakfast and found mixed results with diet quality. Among the 19 studies conducted in other OECD countries (18 peer-reviewed and one government report [Table 2]), including the UK, Denmark, Norway, Japan, Greece, and New Zealand, 13 found improvements in students' dietary outcomes and three found no association. Of the three studies that examined food insecurity, two studies found improvements and one found no association. Of the studies examining dietary outcomes that were considered to have a low risk of bias, the majority (6 out of 7) found improvements in dietary outcomes. All three studies examining food insecurity had a low risk of bias.

Among studies examining diet quality in the United States, four studies examined universal free breakfasts and one examined CEP. Crepinsek and colleagues examined a national sample of elementary schools participating in universal free breakfast versus matched control schools offering traditional (means-tested) breakfasts [66]. This study found that universal free breakfast was positively associated with the consumption of a nutritionally substantive breakfast, including more servings of fruit and dairy. However, there was no association with breakfast skipping or overall dietary intakes over a 24-h period. Similarly, a government report examining the pilot implementation of universal free school breakfasts in six states found no association with nutrients consumed over the course of a day, but students with universal free breakfast were more likely to eat breakfast on all five school days $(p<0.01)$ [50]. A study by Dykstra et al. using a national sample of schools also found that when universal free breakfast was provided, rates of breakfast skipping remained comparable between food-secure and food-insecure students [54]. A study in Boston conducted by Kleinman examined the diets of students and found that those with improved nutrient intakes had significant increases in SBP participation [67]. However, this was not observed among all students receiving school breakfasts (i.e., higher SBP participation was observed among the subsample of students with improved diets, but not all SBP participants had observed improvements in their diets). One cross-sectional study without a comparison group examining universal free school meals in six CEP elementary schools in Virginia found that participation in school meals was associated with consumption levels within recommendations by the Dietary Guidelines for Americans, with students consuming roughly $2.5 \%$ out of the recommended limit of $10 \%$ of daily calories for added sugars (although consumption was not compared with rates prior to implementing CEP) [68].

Two studies examining food insecurity in the U.S. found that CEP was associated with improvements in food security. Poblacion and colleagues used simulation modeling with national data and estimated that CEP would lead to a 3.73\% increase in students becoming food secure and a 3.17\% increase in food security among previously foodinsecure households with children [69]. Similarly, a study by Gross et al. conducted in Maryland found that when compared with students at CEP schools, students attending schools in another district that opted not to participate in CEP had increased odds of being in a household that was food insecure (OR 2.85, 95\% CI 1.67, 4.88) [19].

When examining just universal free breakfast, a study conducted in Norway among 10th grade students found that free breakfast was associated with overall higher Healthy Eating Index (HEI) scores among male students, but no significant change was observed among female students (and this study was considered to have a very high risk of bias) [70]. Additionally, two studies in Wales examined the same dataset with slightly different analyses, and both found that free school breakfasts were associated with an increase in the number of healthy items eaten at breakfast [71,72], with larger increases observed in lower-income schools [72]. Overall, there was no association between free breakfasts and 
breakfast skipping [71], but in sub-analyses, free breakfast was inversely associated with breakfast skipping among students from lower-income households and among students at schools serving higher proportions of students with household poverty [72]. Examining 24-h recalls among a subsample of the students participating in the Welsh study, researchers found that among children receiving a free school breakfast, nearly half also had a breakfast at home prior to coming to school, but this was not associated with significant differences in calories consumed over a $24-\mathrm{h}$ period [73].

When examining school lunch initiatives in Norway, a country where nutrition standards are voluntary, studies measuring students' diets were mixed. One study by Ask et al. examining 9th grade students participating in a pilot free lunch intervention for four months found no association with healthy food scores (although this study was considered to have a very high risk of bias) [74]. A study by IlløKken et al. assessed students ages 10-12 in an intervention school offering free school lunch (compared with a control group comprised of students at the same school and an additional control school) and found that free school lunch was positively associated with healthy food scores after six months of exposure, primarily due to increased consumption of fruits, vegetables, and fish spread [75]. In a separate report of results after following the same students for a year, Vik et al. found that healthy food scores remained significantly higher in the intervention group compared with the control group [76], but there were no significant changes in overall meal frequency (e.g., frequency of eating breakfast, lunch, or dinner on weekdays) [77].

Results were similarly mixed among studies conducted in England. One study conducted by Spence et al. examining UIFSM in two primary schools found that free school lunches had lower consumption of non-milk extrinsic sugar (i.e., added sugar) and biscuits (i.e., shortbread cookies) at lunch, but higher intake of cakes/sweet puddings (i.e., desserts), which were offered daily with school lunches after the main meal was served [78]. The reductions in added sugar were also observed among the students' overall diets (i.e., over the course of an entire day). Another government report by Kitchen and colleagues examining UIFSM found no association with student diets [61], and a third conducted by Gatenby and associates examining a free lunch scheme similarly found no association with overall nutrients consumed throughout the day (although this study was deemed to have a very high risk of bias). Notably, students who received school lunches consumed less at lunch than students who brought their lunches from home, but then compensated by eating more foods outside of the lunch period [79].

In other countries, studies examining school meal programs have generally found positive results concerning dietary quality. One study in Japan examining the mandatory school lunches served in elementary and junior high schools found that consuming school lunches was positively associated with total diet quality [34]. Additionally, a study conducted in the greater Tokyo area among children ages 6-12 found that providing universal (mandatory) school lunches was associated with a reduction in SES-related dietary disparities, particularly regarding fruit and vegetable consumption [80]. A smaller study conducted in one kindergarten class in New Zealand found that offering free lunches to all students in the class was associated with significant reductions in snack food consumption while at school (although this study was assessed to have a very high risk of bias) [81]. In the OPUS School Meal study, which provided free lunches to all 3rd and 4th grade students in nine schools in Demark for three months (and the students ate packed lunches from home for three months) found significant improvements in students' diets, including 16\% higher vegetable intakes $(p<0.0001)$ and $48 \%$ higher fish intakes $(p<0.0001)$, as well as $30 \%$ lower intakes of saturated fats $(p<0.0001)$ [82]. Lastly, a similar study conducted in Denmark among four schools that provided free school lunches for two months (compared with control schools with lunches packed from home only) also found that free meals were associated with improved dietary quality, including reductions in saturated fat and snacks and increases in vegetables and fish [83]. When the school meals were no longer provided at no cost after the two-month period, participation in school lunch became limited and there were no longer improvements in dietary quality observed. 
One study in New Zealand examined universal free breakfast and food insecurity. Mhurchu et al. conducted a study in 14 primary schools in New Zealand with universal free breakfast and found a significant decrease in children's self-reported short-term hunger, but no association with overall food insecurity levels [84]. In contrast, two studies conducted in Greece (as part of the 'DIATROFI' program) with universal free lunches found significant reductions in food insecurity, with the greatest decreases among food-insecure households with hunger $[85,86]$.

\subsection{Attendance}

Researchers have theorized that universal free school meals could increase students' school attendance rates through two mechanisms. The first explanation is that students from low-income households may be motivated to attend school to access the food available. Secondly, improved nutrition from school meals may also decrease the incidence of illness, which could improve attendance. Of the seven peer-reviewed publications and two government reports conducted in the U.S. that examined attendance ( $n=9$ studies [Table 1]), five found a positive association between universal free school meals and attendance (primarily among sub-populations) and four found no association. A limited number of studies ( $n=3$ peer-reviewed publications) have been conducted in other OECD countries, which included Denmark and New Zealand; none found an association with overall attendance and one found a positive association among students with higher school breakfast participation rates in sub-analyses (Table 2). Among the studies considered to have a low risk of bias, half ( 5 out of 10 ) found positive associations with attendance.

When examining studies only implementing universal free breakfast, Bartfeld et al. conducted a study in approximately 1000 elementary schools in Wisconsin with varying breakfast models (including universal free and means-tested programs) and found that for lower-income students only, universal free breakfast was associated with an increase in the percent of days attended ( 0.24 percentage point increase; $p=0.023)$ and a decrease in the percent of students with low attendance (3.5 percentage point decrease; $p<0.001)$ [87]. Similarly, in the Kleinman et al. study in Boston ( $n=97$ students), improvements in attendance were observed only among the students who improved their nutritional status (which was associated with participation in the SBP) [67]. Leos-Urbel and colleagues also observed improvements in attendance among subpopulations within New York City elementary and middle schools; universal free breakfast was associated with a small increase in attendance among low-income Black students and higher-income Asian students [48]. In the study conducted by Ribar et al. in North Carolina among elementary schools that stopped offering universal free breakfasts, no impact on attendance was observed [49]. Lastly, two government reports examining the pilot of the universal free school breakfast program in six states found no association with attendance after either one year [50] or three years [51] of exposure.

Two studies examined universal free school meals and attendance. Gordanier et al. evaluated 3-8th grade students throughout South Carolina and found CEP was inversely associated with absences (i.e., improved attendance) among elementary students but not middle school students [88]. Bartfeld and colleagues examined elementary schools throughout Wisconsin and found that after two years of exposure, there were no associations between CEP and overall attendance rates, but a 3.5 percentage point reduction was observed in the percent of low-income students with low attendance $(p=0.045)$ [89]. It was also noteworthy that no associations with attendance were observed within the first year of implementation. Similarly, Schwartz et al. found no association between Provision 2 and overall attendance rates among middle school students in New York City [39].

Among other OECD countries, in the study conducted by Mhurchu et al. in the 14 schools with a free school breakfast program, as well as in the study by Munday and colleagues examining free lunches among a kindergarten classroom (both conducted in New Zealand), neither found an association with overall attendance rates (although the study by Munday et al. was considered to have a very high risk of bias) [81,84]. However, 
in secondary analyses examining students with higher school breakfast participation (attendance at least $50 \%$ of the time at school breakfast), Mhurchu et al. found small but significant improvements in attendance $(1.6 \%$ increase; $p=0.016)$. Laursen and associates also found no association between a free school lunch program and overall attendance among 3rd and 4th grade students in Denmark [90]. However, most of the students in these studies had limited exposure to free meals (ranging from 2.5 to 10 months).

\subsection{Academic Performance}

Academic performance may also be influenced by universal free school meals, both directly through potential improvements in nutrition, as well as indirectly through potential increases in school attendance rates [17,91-94]. Among the ten studies in the U.S. ( $n=8$ peer-reviewed and $n=2$ government reports [Table 1]), all three examining CEP found positive associations with academic performance, while the six studies examining universal free breakfast were mixed. Similarly, one government-funded project conducted in England found a positive association between universal free school meals and academic performance while three studies (conducted in New Zealand and Wales) found no association when examining universal free breakfast ( $n=4$ studies [Table 2]). Specifically among the studies with a low risk of bias, 3 out of 7 found a positive association with academic performance.

Of the studies examining universal free breakfast, Kleinman et al.'s study in Boston found significant improvements in academic performance (i.e., math test scores), but only among students who improved their nutrient intakes [67]. Similarly, Walhstrom and colleagues observed positive trends in standardized achievement test scores within six elementary schools (compared with three control schools) in Minnesota after piloting universal free breakfasts, although no statistical analyses were conducted and this study was considered to have a very high risk of bias [22]. In Bartfeld et al.'s study in Winsonsin elementary schools, universal free breakfast was positively associated with math $(0.07 \mathrm{SD}$ higher, $p=0.001)$ and reading (0.04 SD higher, $p=0.035)$ test scores, but only among higher income students [87]. Contrasting with those studies, Leos-Ubel et al.'s study among elementary and middle school students in New York City [48], Ribar et al.'s study in North Carolina [49], and the two government report examining the pilot of universal free breakfast found no significant associations with test scores after one or three years of exposure [50,51].

Among studies examining school meal provisions that include lunch in the U.S., Gordanier et al.'s study among 3-8th grade students in South Carolina found that CEP was positively associated with math test scores ( 0.06 standard deviation increase) among elementary students, but did not have any significant associations with reading scores in elementary school, nor any test scores among middle school students [88]. Similarly, Schwartz et al. found a positive association between Provision 2 and academic performance among middle school students in New York City; math and English Language Arts standardized test scores were significantly higher, with the greatest improvements observed among higher-income students [39]. Lastly, in a study conducted by Taylor and colleagues in Vermont, CEP was associated with higher perceptions of improved academic performance and readiness to learn according to school staff surveys, although no direct, objective measurements of academic performance were collected (and the study was considered to have a very high risk of bias) [95].

In studies conducted in other OECD countries (i.e., New Zealand and the UK), Mhurchu et al. found no association between a free school breakfast program and academic performance in New Zealand primary schools [84]. Similarly, no association was found within primary schools in Wales between implementation of a free breakfast initiative and cognitive scores among two studies examining the same data using slightly different analyses [71,72]. However, in a government report examining UIFSM, free lunch was associated with improved academic performance; students made on average $4-8$ weeks more progress compared with similar students in control schools [61]. 


\subsection{Body Mass Index}

One concern about universal free school meals has been the potential adverse impact on children's BMI, particularly if a child receives a breakfast at home and then receives a second breakfast and lunch at school [38,39]. However, if healthier meals are provided by schools, they may reduce the risk of obesity to the extent that they replace less nutritionally balanced foods with higher quality school meals $[96,97]$. The evidence that school meals are on average healthier than lunches brought from home supports this theory $[25,27]$. Further, it may be that increased satiety from healthy lunch consumption leads to reduced consumption of less healthy foods after school [65]. To date, only one peer-reviewed study and one government report in the U.S. have examined BMI and universal free school meals ( $n=2$ studies [Table 1]), and five studies $(n=4$ peer-reviewed publications and $n=1$ government report [Table 2]) have been conducted in other OECD countries including England, Norway, and the Netherlands. The majority (6 out of 7) found either no association with BMI or a reduced probability of developing overweight and obesity. Among the limited number of studies considered to have a low risk of bias, 2 out of 3 found universal free school meals were associated with lower BMIs among students.

In the U.S., Schwartz and colleagues found no association between free lunches offered through Provision 2 and BMI among middle school students in New York City [39]. In sub-analyses, Provision 2 was associated with a $2.5 \%$ reduced probability $(p<0.01)$ of obesity among higher-income students. In a government report examining the pilot of universal free breakfast, there was no association with the prevalence of overweight after one year of exposure to free school breakfasts [50].

A study in the Netherlands conducted by Bartelink et al. found that providing children ages 4-12 with a free lunch (in additional to some structured physical activity after lunch) was inversely associated with BMI z-score after two years of follow-up (standardized effect size $=-0.083, p=0.01$ ) [98]. In a study conducted by Ask et al. among 10th graders in Norway, providing free breakfasts also appeared to be protective against excess weight gain; BMI remained unchanged among students receiving free school breakfast, whereas there was a significant increase in the BMI of students in the control group over the span of four months (although this study was deemed to have a very high risk of bias) [70]. Another study by Ask et al. conducted in Norway among 9th grade students found no association between a pilot free lunch program and BMI after four months of exposure, and this study also was considered to have a very high risk of bias [74]. Similarly a government report in England found no association between UIFSM and BMI [61]. These results contrast with a study conducted in Norway that found a free school lunch program was associated with higher BMI z-scores, compared with a decrease in BMI z-scores among the control students $(\mathrm{F}=10.007, p=0.002)$, despite the healthier food scores observed among the students with free lunch [76].

\subsection{Finances}

Concerns have also been raised about the impact of universal free school meals on school finances, specifically due to the increase in costs from preparing and serving more meals [38,39]. However, 5 out of the 6 peer-reviewed publications and government reports in the U.S. reported that increased food and labor costs were balanced by increased revenues from school meals served through federal reimbursements. Of note, these estimates of the cost of implementation do not include the increase in cost to the U.S. federal government. (Table 1). Additionally, one study in Scotland estimated the overall costs of providing universal free lunches (Table 2). Among these studies, only one was considered to have a low risk of bias, and this study found positive outcomes for school finances with universal free school meals.

In the U.S., a study in Texas that examined a school district with Provision 2 found that implementation was associated with a $5 \%$ increase in annual revenue (statistical significance was not assessed and the study was assessed to have a very high risk of bias) [55]. Similarly, a government report examining the pilot of universal free school 
breakfasts found that there was an increase in labor costs, but these were more than offset by the increase in meals served (and thus an increase in federal reimbursements), resulting in an average savings of USD 0.11 per breakfast served for districts [50]. Another government report examining the USDA No-Fee School Meal Pilot Program in three states found that providing universal free school meals was associated with a $33 \%$ increase in federal reimbursement overall and reduced administrative costs [56]. In a third government report examining $\mathrm{CEP}$, this provision was associated with increased federal meal reimbursements (increase of $5.6 \%$ for NSLP and 1.9\% for SBP) [37]. Staff also spent significantly less time distributing and processing applications for free and reduced-price meals and/or verifying student eligibility, which resulted in an average savings of $68 \mathrm{~min}$ per student annually (translating to a labor-saving cost of approximately USD 29 per student per year). This time savings is partially offset by an average $30 \mathrm{~min} /$ student increase in staff time annually to claim reimbursable meals $(p<0.01)$. Overall, this government report found that federal funding via reimbursements per student increased by $13.5 \%$ (or USD 5.33 per student annually), resulting in potential net gains for school districts participating in CEP. Similarly, in a study conducted in Vermont, school staff (e.g., principals, food service staff, and business managers) perceptions were measured using an online survey, and roughly half of participants perceived that school finances had improved (52.4\%), while only $44 \%$ perceived that the school meal program deficit was reduced [95]. No objective measurements of school finances were collected in this study. Conversely, a government report examining schools that eliminated reduced-price fees within 5 states found that federal reimbursements for the school meals served only partially offset the program costs with higher participation rates (although this report was deemed to have a very high risk of bias) [57]. In Scotland, a government report examining school meals found that the costs of preparing meals varied (from $£ 1.79$ to $£ 4.65$ per meal). The cost per meal decreased as the number of meals served increased, likely due in part to economies of scale (e.g., buying in bulk or through contract negotiations) [62]. 
Table 1. Characteristics of studies conducted in the United States included in the systematic review.

\begin{tabular}{|c|c|c|c|c|c|c|c|}
\hline Author, Year & $\begin{array}{c}\text { Location; } \\
\text { Participant } \\
\text { Characteristics }\end{array}$ & Study Design & Year(s) & $\begin{array}{l}\text { Universal Meal } \\
\text { Provision }\end{array}$ & Outcome Measure(s) & Results & Risk of Bias $^{2}$ \\
\hline $\begin{array}{l}\text { Adams et al. } \\
2020 \text { [68] }\end{array}$ & $\begin{array}{c}\text { Virginia; } 6 \text { Title I } \\
\text { elementary schools } \\
\text { (grades } 1-5), n=1155 \\
\text { plate waste } \\
\text { measurements }\end{array}$ & CS & 2016 & CEP & $\begin{array}{l}\text { Diet: Added sugar } \\
\text { consumption at lunch } \\
\text { (measured using plate waste } \\
\text { determined using digital } \\
\text { photography) }\end{array}$ & $\begin{array}{l}\text { In CEP schools, foods selected had } \\
\text { on average } 11.2 \mathrm{~g} \text { of added sugar } \\
\text { and beverages had on average } 11.0 \mathrm{~g} \\
\text { of added sugar. Students consumed } \\
\text { on average } 6.6 \mathrm{~g} \text { of added sugar } \\
\text { from foods and } 3.6 \mathrm{~g} \text { of added sugar } \\
\text { from beverages }(\sim 10 \% \text { of calories } \\
\text { consumed from foods and } \sim 35 \% \\
\text { calories consumed from beverages; } \\
\sim 2.5 \% \text { of added sugars consumed } \\
\text { out of the } 10 \% \text { recommend by the } \\
\text { Dietary Guidelines for Americans) }\end{array}$ & Low \\
\hline $\begin{array}{l}\text { Bartfeld et al. } \\
2019 \text { [87] }\end{array}$ & $\begin{array}{c}\text { Wisconsin; } \\
\text { elementary schools } \\
\text { throughout the state } \\
\text { with varying } \\
\text { breakfast models } \\
\text { (including universal } \\
\text { free and mean-tested) }\end{array}$ & $\begin{array}{l}\text { QE: Pre/post } \\
\text { (with control) }\end{array}$ & $\begin{array}{l}2009-2010 \text { to } \\
2013-2014 \text { SY }\end{array}$ & USBP & $\begin{array}{l}\text { (1) Attendance: percent of } \\
\text { school days attended and } \\
\text { low attendance (i.e., } \\
\text { attending fewer than } 95 \% \text { of } \\
\text { available days) measured } \\
\text { among student in grades } 1-5 \\
\text { (2) Academic Performance: } \\
\text { test scores in reading and } \\
\text { math measured among } \\
\text { student in grades 3-5 }\end{array}$ & $\begin{array}{l}\text { (1) USBP was not associated with } \\
\text { attendance overall, but in } \\
\text { sub-analyses was associated with } \\
\text { increased attendance among } \\
\text { low-income students; USBP was } \\
\text { associated with a } 0.24 \% \mathrm{pt} \uparrow \text { in the } \% \\
\text { of days attended ( } p=0.023 \text { ) and a } \\
3.5 \% \mathrm{pt} \downarrow \text { in the percent of students } \\
\text { with low attendance }(p<0.001) \\
\text { (2) USBP was not associated with } \\
\text { academic performance overall, but } \\
\text { in sub-analyses was associated with } \\
0.07 \text { SD high math scores }(p=0.001) \\
\text { and } 0.04 \text { SD higher reading scores } \\
\text { ( } p=0.035) \text { among higher-income } \\
\text { students }\end{array}$ & Low \\
\hline
\end{tabular}


Table 1. Cont.

\begin{tabular}{|c|c|c|c|c|c|c|c|}
\hline Author, Year & $\begin{array}{c}\text { Location; } \\
\text { Participant } \\
\text { Characteristics }\end{array}$ & Study Design & Year(s) & $\begin{array}{c}\text { Universal Meal } \\
\text { Provision }\end{array}$ & Outcome Measure(s) & Results & Risk of Bias ${ }^{2}$ \\
\hline $\begin{array}{l}\text { Bartfeld et al. } \\
2020 \text { [89] }\end{array}$ & $\begin{array}{l}\text { Wisconsin; } 37 \text { CEP } \\
\text { elementary schools } \\
\text { and } 108 \text { comparison } \\
\text { (i.e., eligible } \\
\text { non-CEP) elementary } \\
\text { schools (grade 1-5) }\end{array}$ & $\begin{array}{l}\text { QE: Pre/post } \\
\text { (with control) }\end{array}$ & $\begin{array}{l}2013-2014 \text { to } \\
2015-2016 \mathrm{SY}\end{array}$ & CEP & $\begin{array}{l}\text { Attendance: percent of } \\
\text { school days attended and } \\
\text { low attendance (i.e., } \\
\text { attending fewer than } 95 \% \text { of } \\
\text { available days) }\end{array}$ & $\begin{array}{l}\text { After two years of exposure, CEP } \\
\text { was associated in a } 3.5 \% \mathrm{pt} \downarrow \text { in low } \\
\text { attendance ( } p=0.045) \text { compared } \\
\text { with control schools. In } \\
\text { sub-analyses, CEP was associated } \\
\text { with a } 4.2 \% \text { pt } \downarrow \text { in the probability of } \\
\text { low attendance ( } p=0.035 \text { ) among } \\
\text { lower-income students. }\end{array}$ & Low \\
\hline $\begin{array}{l}\text { Bernstein et al. } \\
\text { 2004 [51] } \\
\text { (USDA Report) }\end{array}$ & $\begin{array}{l}\text { USA; Six school } \\
\text { districts (in six } \\
\text { states); elementary } \\
\text { schools within each } \\
\text { district randomly } \\
\text { assigned to USBP } \\
\text { ( } n=79 \text { schools) or } \\
\text { control (maintain } \\
\text { means-tested SBP; } \\
n=74 \text { schools). }\end{array}$ & $\begin{array}{l}\text { QE: Pre/post } \\
\text { (with control) }\end{array}$ & $\begin{array}{l}1999-2000 \text { to } \\
2002-2003 \text { SY }\end{array}$ & USBP & $\begin{array}{l}\text { (1) Participation } \\
\text { (2) Attendance } \\
\text { (3) Academic Performance: } \\
\text { test scores in reading and } \\
\text { math }\end{array}$ & $\begin{array}{l}\text { (1) Offering free school breakfasts } \\
\text { was associated with an } \uparrow \text { in } \\
\text { breakfast participation that was } \\
\text { maintained for three years (a } 15 \% \text { pt } \\
\text { gain after three years; } p=0.01 \text { ). } \\
\text { (2) No association with attendance } \\
\text { (3) No association with test scores }\end{array}$ & Low \\
\hline $\begin{array}{l}\text { Brown } 2009 \text { [57] } \\
\text { (GAO Report) }\end{array}$ & $\begin{array}{l}\text { USA; } 5 \text { states and } \\
14 \text { districts in other } \\
\text { states that } \\
\text { implemented ERP }\end{array}$ & $\begin{array}{l}\text { QE: Pre/post (no } \\
\text { control) }\end{array}$ & 2007-2008 SY & ERP & $\begin{array}{l}\text { (1) Participation } \\
\text { (2) } \underline{\text { Finances }}\end{array}$ & $\begin{array}{l}\text { (1) ERP was associated with an } \uparrow \text { in } \\
\text { participation in the SBP (9\% average } \\
\text { increase) and NSLP ( } 11 \% \text { average } \\
\text { increase) among students who were } \\
\text { eligible for reduced-price meals } \\
\text { (2) Federal reimbursements only } \\
\text { partially offset programs costs for } \\
\text { the participation states/school } \\
\text { districts }\end{array}$ & $\begin{array}{l}\text { Very } \\
\text { High }\end{array}$ \\
\hline
\end{tabular}


Table 1. Cont.

\begin{tabular}{|c|c|c|c|c|c|c|c|}
\hline Author, Year & $\begin{array}{c}\text { Location; } \\
\text { Participant } \\
\text { Characteristics }\end{array}$ & Study Design & Year(s) & $\begin{array}{c}\text { Universal Meal } \\
\text { Provision }\end{array}$ & Outcome Measure(s) & Results & Risk of Bias $^{2}$ \\
\hline $\begin{array}{c}\text { Crepinsek et al. } \\
2006 \text { [66] }\end{array}$ & $\begin{array}{c}\text { USA; national } \\
\text { sample of elementary } \\
\text { schools (153 matched } \\
\text { schools in six school } \\
\text { districts with USBP } \\
\text { or means-tested } \\
\text { breakfast }[n=4358 \\
\text { students, } \\
\text { grades } 2-6])\end{array}$ & Cluster RCT & $\begin{array}{c}1999-2000 \text { to } \\
2002-2003\end{array}$ & USBP & $\begin{array}{l}\text { Diet: food and nutrient } \\
\text { intakes (measured using one } \\
\text { 24-h recall) }\end{array}$ & $\begin{array}{l}\text { USBP was positively associated with } \\
\text { the consumption of a nutritionally } \\
\text { substantive breakfast }(80 \% \text { vs. } 76 \% \text {; } \\
p<0.01) \text {, including increased servings } \\
\text { of fruit and dairy. There was no } \\
\text { association with overall breakfast } \\
\text { skipping or overall dietary intakes } \\
\text { over a } 24-h \text { period. }\end{array}$ & Low \\
\hline $\begin{array}{c}\text { Dykstra et al. } \\
2016[54]\end{array}$ & $\begin{array}{l}\text { Philadelphia, PA; } 16 \\
\text { schools (students } \\
\text { grade } 4-6 ; n=821 \\
\text { student/parent } \\
\text { dyads) with USBP }\end{array}$ & CS & 2013 & USBP & $\begin{array}{l}\text { (1) Participation } \\
\text { (2) Diet: Breakfast skipping } \\
\text { (measured using the } \\
\text { Breakfast Patterns Survey } \\
\text { [student self-report]) }\end{array}$ & $\begin{array}{l}\text { (1) On the day of data collection, } \\
38.8 \% \text { of students reported consuming } \\
\text { a school breakfast and participating in } \\
\text { the SBP on } 32.1 \% \text { of possible days } \\
\text { (with } 87.0 \% \text { of students participating } \\
\text { in the SBP at least } 1 \text { day during the } \\
\text { fall semester). There was significantly } \\
\text { higher participation among minority } \\
\text { students (Black students participated } \\
\text { on } 36.5 \% \text { of days, Hispanic students } \\
\text { participated on } 25.0 \% \text { of days, and } \\
\text { white students participated on } 18.7 \% \\
\text { of days ( } p<0.001 \text { ). No differences in } \\
\text { SBP participation by free or } \\
\text { reduced-price eligibility or by food } \\
\text { insecurity levels. } \\
\text { (2) } 16.9 \% \text { of students reported } \\
\text { skipping breakfast on the morning of } \\
\text { data collection. Rates of skipping } \\
\text { breakfast did not differ between } \\
\text { students from food-insecure } \\
\text { households and students from } \\
\text { food-secure households. }\end{array}$ & High \\
\hline
\end{tabular}


Table 1. Cont.

\begin{tabular}{|c|c|c|c|c|c|c|c|}
\hline Author, Year & $\begin{array}{c}\text { Location; } \\
\text { Participant } \\
\text { Characteristics }\end{array}$ & Study Design & Year(s) & $\begin{array}{l}\text { Universal Meal } \\
\text { Provision }\end{array}$ & Outcome Measure(s) & Results & Risk of Bias $^{2}$ \\
\hline $\begin{array}{l}\text { Gordanier et al. } \\
\quad 2020 \text { [88] }\end{array}$ & $\begin{array}{l}\text { South Carolina; } \\
\text { elementary and } \\
\text { middle schools } \\
\text { throughout the state } \\
\text { that adopted CEP vs. } \\
\text { non-CEP schools } \\
\text { (both eligible and } \\
\text { non-eligible schools), } \\
\text { students grade 3-8 }\end{array}$ & $\begin{array}{l}\text { QE: Pre/post } \\
\text { (with control) }\end{array}$ & $\begin{array}{l}2013-2014 \text { to } \\
2015-2016 \text { SY }\end{array}$ & CEP & $\begin{array}{l}\text { (1) Attendance } \\
\text { (2) Academic Performance: } \\
\text { State standardized test } \\
\text { scores (Math and English } \\
\text { Language Acquisition] }\end{array}$ & $\begin{array}{l}\text { (1) CEP was associated with a } \downarrow \text { in } \\
\text { absences among elementary } \\
\text { students }(-0.231 \text { days per year; } \\
p<0.05) \text {. No significant associations } \\
\text { were observed with absences among } \\
\text { middle school students. } \\
\text { (2) CEP was associated with an } \uparrow \text { in } \\
\text { math test scores among elementary } \\
\text { students }(0.06 \text { SD; } p<0.01) \text {. No } \\
\text { significant associations were } \\
\text { observed for math scores among } \\
\text { middle school students nor for } \\
\text { reading scores for elementary or } \\
\text { middle school students. }\end{array}$ & Low \\
\hline $\begin{array}{l}\text { Gross et al. } \\
2019 \text { [19] }\end{array}$ & $\begin{array}{c}\text { Maryland; One } \\
\text { district with } 5 \text { CEP } \\
\text { schools and one } \\
\text { matched control } \\
\text { district with } 3 \\
\text { schools (CEP-eligible } \\
\text { but not participating), } \\
n=427 \text { household } \\
\text { surveys }\end{array}$ & CS & 2017 & CEP & $\begin{array}{l}\text { Diet: Food insecurity } \\
\text { (measured using the USDA } \\
\text { Six-Item Short Form of the } \\
\text { Food Security Survey } \\
\text { Module [parent report] }\end{array}$ & $\begin{array}{l}\text { CEP was associated reduced odds of } \\
\text { household food insecurity (i.e., } \\
\text { students had twice the odds of } \\
\text { being in a food-insecure household } \\
\text { if they attended a school that was } \\
\text { CEP-eligible but not participating } \\
\text { [OR 2.85, 95\% CI 1.67, } 4.88] \text { ). }\end{array}$ & High \\
\hline $\begin{array}{l}\text { Khan et al. } \\
2011 \text { [53] }\end{array}$ & $\begin{array}{l}\text { Vermont; one middle } \\
\text { school (grades 6-8) } \\
\text { with USBP, } n=373 \\
\text { students }\end{array}$ & CS & 2005 & USBP & $\begin{array}{l}\text { Diet: Food insecurity } \\
\text { (measured using a 9-item } \\
\text { validated survey [student } \\
\text { self-report]) }\end{array}$ & $\begin{array}{l}\text { Food insecure children were } \\
\text { significantly less likely to eat } \\
\text { breakfast at home compared with } \\
\text { food secure children }(32.9 \% \text { vs. } \\
18.6 \% \text { of students did not eat } \\
\text { breakfast at home; } p=0.007) \text {, and } \\
91.3 \% \text { of food insecure students } \\
\text { reported eating breakfast at school. }\end{array}$ & High \\
\hline
\end{tabular}


Table 1. Cont.

\begin{tabular}{|c|c|c|c|c|c|c|c|}
\hline Author, Year & $\begin{array}{c}\text { Location; } \\
\text { Participant } \\
\text { Characteristics }\end{array}$ & Study Design & Year(s) & $\begin{array}{c}\text { Universal Meal } \\
\text { Provision }\end{array}$ & Outcome Measure(s) & Results & Risk of Bias $^{2}$ \\
\hline $\begin{array}{l}\text { Kleinman et al. } \\
2002 \text { [67] }\end{array}$ & $\begin{array}{l}\text { Boston, } \\
\text { Massachusetts; three } \\
\text { schools before and } \\
\text { after implementing } \\
\text { USBP }(n=97 \\
\text { students in } \\
\text { grades } 4-6)\end{array}$ & $\begin{array}{l}\text { QE: Pre/post (no } \\
\text { control) }\end{array}$ & $\begin{array}{l}1998-1999 \text { to } \\
1999-2000 \text { SY }\end{array}$ & USBP & $\begin{array}{l}\text { (1) Diet: Nutrient intakes } \\
\text { and hunger (measured using } \\
\text { 24-h dietary recalls and } \\
\text { 5-item version of the Child } \\
\text { Hunger Index Child Report } \\
\text { survey [student } \\
\text { self-report] + an 8-item } \\
\text { hunger/food insufficiency } \\
\text { questionnaire [parent } \\
\text { report]) } \\
\text { (2) Attendance } \\
\text { (3) Academic Performance: } \\
\text { test scores in math, reading, } \\
\text { science, and social studies } \\
\text { (based on school records) }\end{array}$ & $\begin{array}{l}\text { (1) USBP was not associated with } \\
\text { differences in the } \\
\text { percent of students who were } \\
\text { nutritionally at risk overall, but } \\
\text { children who had improvements in } \\
\text { nutritional status had significant } \uparrow \\
\text { in USBP participation }(p<0.001 \text { ) } \\
\text { and } \downarrow \text { in self-reported hunger (mean } \\
\text { change in hunger score of }-1.4 \text {; } \\
p<0.0001 \text { ). } \\
\text { (2) Among students with improved } \\
\text { nutrient intakes, } \\
\text { there was a significant } \downarrow \text { in absences } \\
\text { (-4.4 days } \\
\text { absent; } p<0.01 \text { ). } \\
\text { (3) Among students with improved } \\
\text { nutrient intakes, } \\
\text { there was a positive association } \\
\text { with math grades } \\
\text { (mean change } 0.6 ; p<0.05 \text { ). No } \\
\text { other significant } \\
\text { associations were observed } \\
\text { with grades. }\end{array}$ & High \\
\hline
\end{tabular}


Table 1. Cont.

\begin{tabular}{|c|c|c|c|c|c|c|c|}
\hline Author, Year & $\begin{array}{c}\text { Location; } \\
\text { Participant } \\
\text { Characteristics }\end{array}$ & Study Design & Year(s) & $\begin{array}{c}\text { Universal Meal } \\
\text { Provision }\end{array}$ & Outcome Measure(s) & Results & Risk of Bias ${ }^{2}$ \\
\hline $\begin{array}{l}\text { Leos-Urbel et al. } \\
2013 \text { [48] }\end{array}$ & $\begin{array}{l}\text { New York City, New } \\
\text { York; elementary and } \\
\text { middle schools } \\
\text { before and after } \\
\text { implementing USBP } \\
(n=723,843 \text { students } \\
\text { in grades } 3-8)\end{array}$ & $\begin{array}{c}\text { QE: Pre/post (no } \\
\text { control) }\end{array}$ & $\begin{array}{l}2002-2003 \text { to } \\
2003-2004 \text { SY }\end{array}$ & USBP & $\begin{array}{l}\text { (1) Participation } \\
\text { (2) Attendance } \\
\text { (3) Academic performance: } \\
\text { scores in statewide English } \\
\text { and math tests }\end{array}$ & $\begin{array}{l}\text { (1) USBP was associated with } \uparrow \\
\text { breakfast } \\
\text { participation (an increase of } 5 \% \\
\text { among students previously eligible } \\
\text { for free meals [ } p<0.05] \text { )., } 21 \% \\
\text { among students previously eligible } \\
\text { for reduced price meals [ } p<0.01] \text {, } \\
\text { and } 36 \% \text { among students previously } \\
\text { eligible for full-price meals } \\
{[p<0.01] \text { ). }} \\
\text { (2) There was no association with } \\
\text { overall attendance rates. In } \\
\text { sub-analyses, universal free } \\
\text { breakfast was associated with a } \\
\text { small } \uparrow \text { in attendance among } \\
\text { low-income black students ( } 0.37 \% \text {; } \\
p<0.01 \text { ) and higher-income Asian } \\
\text { students ( } 0.25 \% \text {; } p<0.05 \text { ). } \\
\text { (3) There was no association with } \\
\text { academic performance. }\end{array}$ & Low \\
\hline
\end{tabular}


Table 1. Cont.

\begin{tabular}{|c|c|c|c|c|c|c|c|}
\hline Author, Year & $\begin{array}{c}\text { Location; } \\
\text { Participant } \\
\text { Characteristics }\end{array}$ & Study Design & Year(s) & $\begin{array}{l}\text { Universal Meal } \\
\text { Provision }\end{array}$ & Outcome Measure(s) & Results & Risk of Bias ${ }^{2}$ \\
\hline $\begin{array}{c}\text { Logan et al. } \\
2014 \text { [37] } \\
\text { (Report to } \\
\text { USDA) }\end{array}$ & $\begin{array}{c}\text { National; } 7 \text { states } \\
\text { (285 participating } \\
\text { LEAs }{ }^{1} \text { and } 528 \\
\text { matched } \\
\text { non-participating } \\
\text { LEAs) }\end{array}$ & $\begin{array}{l}\text { QE: Pre/post } \\
\text { (with control) }\end{array}$ & $\begin{array}{l}2009-2010 \text { to } \\
2012-2013 \text { SY }\end{array}$ & CEP & $\begin{array}{l}\text { (1) Participation } \\
\text { (2) Finances }\end{array}$ & $\begin{array}{l}\text { (1) CEP was associated with } \uparrow \\
\text { participation (5.2\% increase in NSLP } \\
\text { participation, } p<0.01 ; 9.4 \% \text { increase } \\
\text { in SBP participation, } p<0.01 \text { ) } \\
\text { (2) CEP was associated with } \uparrow \\
\text { federal reimbursement ( } 5.6 \% \text { for } \\
\text { NSLP [3.5\% pts, } p<0.01] ; 1.9 \% \text { for } \\
\text { SBP [3.5\% pts, } p<0.01] \text { ). CEP was } \\
\text { also associated with } \downarrow \text { in time spent } \\
\text { by staff distributing/processing } \\
\text { applications for FRP meals ( } p<0.01 \text { ) } \\
\text { and verifying eligibility of students } \\
\text { ( } p<0.01 \text { ), resulting in a combined } \\
\text { savings of on average } \\
68 \text { min/student annually, which } \\
\text { represents a labor saving cost of } \\
\text { approximately USD } 29 / \text { student } \\
\text { annually (partially offset by } \\
\text { increases in staff time to claim } \\
\text { reimbursable meals [increase of } \\
30 \text { min/student annually, } p<0.01] \text {. } \\
\text { Federal funding (reimbursements) } \\
\text { per student } \uparrow \text { by } 13.5 \% \text { (USD } \\
5.33 / \text { student annually } p<0.01 \text { ), and } \\
\text { there was no impact on non-Federal } \\
\text { finances (e.g., state reimbursement } \\
\text { or student payments for } \\
\text { non-reimbursable meals) resulting } \\
\text { in potential net gains for LEAs } \\
\text { participating in CEP. }\end{array}$ & Low \\
\hline
\end{tabular}


Table 1. Cont.

\begin{tabular}{|c|c|c|c|c|c|c|c|}
\hline Author, Year & $\begin{array}{c}\text { Location; } \\
\text { Participant } \\
\text { Characteristics }\end{array}$ & Study Design & Year(s) & $\begin{array}{c}\text { Universal Meal } \\
\text { Provision }\end{array}$ & Outcome Measure(s) & Results & Risk of Bias ${ }^{2}$ \\
\hline $\begin{array}{l}\text { McLaughlin } \\
\text { et al. } 2002 \text { [50] } \\
\text { (USDA Report) }\end{array}$ & $\begin{array}{l}\text { USA; Six schools } \\
\text { districts (in six } \\
\text { states); elementary } \\
\text { schools within each } \\
\text { district randomly } \\
\text { assigned to USBP } \\
\text { ( } n=79 \text { schools) or } \\
\text { control (maintain } \\
\text { means-tested SBP; } \\
n=74 \text { schools). }\end{array}$ & Cluster RCT & $\begin{array}{l}1999-2000 \text { to } \\
2000-2001 \text { SY }\end{array}$ & USBP & $\begin{array}{l}\text { (1) Participation } \\
\text { (2) Diet: Frequency of } \\
\text { breakfast and nutrients } \\
\text { consumed (measured by } \\
24 \text { h recall [with parent } \\
\text { assistance]) } \\
\text { (3) Attendance } \\
\text { (4) Academic Performance: } \\
\text { test scores for math and } \\
\text { reading and cognitive tests } \\
\text { (5) BMI: objective } \\
\text { measurements at school } \\
\text { (6) Finances }\end{array}$ & $\begin{array}{l}\text { (1) USBP was associated with } 16 \% \\
\text { pt } \uparrow \text { in participation }(p=0.01) \text {, with } \\
\text { the largest increases among } \\
\text { students not previously eligible for } \\
\text { free or reduced-price breakfasts. } \\
\text { (2) Students in schools with USBP } \\
\text { were more likely to eat breakfast on } \\
\text { all five school days ( } p<0.01 \text { ) but } \\
\text { there was no difference observed in } \\
\text { most nutrients consumed over the } \\
\text { course of a day. } \\
\text { (3) There were no differences } \\
\text { observed in attendance. } \\
\text { (4) There were no differences } \\
\text { observed in math or reading score } \\
\text { gains nor cognitive functioning. } \\
\text { (5) There were no differences } \\
\text { observed in the prevalence of } \\
\text { overweight. } \\
\text { (6) The increases in breakfast } \\
\text { participation resulted in lower } \\
\text { per-meal labor costs in schools with } \\
\text { USBP, with the increases in labor } \\
\text { costs offset by the increase in meals } \\
\text { served (average cost per breakfast } \\
\text { served was USD 0.11 lower). }\end{array}$ & $\begin{array}{l}\text { High/ } \\
\text { Low }^{2}\end{array}$ \\
\hline
\end{tabular}


Table 1. Cont.

\begin{tabular}{|c|c|c|c|c|c|c|c|}
\hline Author, Year & $\begin{array}{c}\text { Location; } \\
\text { Participant } \\
\text { Characteristics }\end{array}$ & Study Design & Year(s) & $\begin{array}{l}\text { Universal Meal } \\
\text { Provision }\end{array}$ & Outcome Measure(s) & Results & Risk of Bias $^{2}$ \\
\hline $\begin{array}{c}\text { Poblacion et al. } \\
\text { 2017 [69] }\end{array}$ & $\begin{array}{l}\text { USA; national dataset } \\
\text { of households with } \\
\text { children and school } \\
\text { meal participation } \\
\text { rates to model } \\
\text { potential impact of } \\
\text { CEP }\end{array}$ & SM & 2014 & CEP & $\begin{array}{l}\text { Diet: food insecurity } \\
\text { (measured using simulation } \\
\text { modeling based on change } \\
\text { in income-to-poverty ratios } \\
\text { of food-insecure people in } \\
\text { households with children } \\
\text { using prevalence estimates } \\
\text { from national data) }\end{array}$ & $\begin{array}{l}\text { Free lunches from CEP was } \\
\text { associated with an estimated } \\
\text { increase of } 3.73 \% \text { of students } \\
\text { becoming food secure (due to } \\
\text { families increasing their food } \\
\text { purchasing power). When } \\
\text { examining the combined impact of } \\
\text { USBP and NSLP with CEP, the } \\
\text { estimated increase in purchasing } \\
\text { power was associated with } 3.23 \% \text { of } \\
\text { food insecure households with } \\
\text { children becoming food secure. }\end{array}$ & Low \\
\hline $\begin{array}{c}\text { Pokorney et al. } \\
2019 \text { [58] }\end{array}$ & $\begin{array}{l}\text { Pennsylvania; all } \\
\text { CEP schools }(n=654) \\
\text { and eligible non-CEP } \\
\text { schools }(n=1221)\end{array}$ & $\begin{array}{l}\text { QE: Pre/post } \\
\text { (with control) }\end{array}$ & $\begin{array}{l}2013-2014 \text { to } \\
2014-2015 \text { SY }\end{array}$ & CEP & Participation & $\begin{array}{l}\text { CEP was associated with an } 8 \% \uparrow \text { in } \\
\text { lunch served (RR }=1.08,95 \% \text { CI } \\
1.03,1.12) \text {. In sub-analyses, CEP was } \\
\text { associated with an } 69 \% \uparrow \text { in lunches } \\
\text { served among higher-income } \\
\text { students (RR }=1.69,95 \% \text { CI } 1.11 \text {, } \\
2.56) \text {, but also a slight decrease } \\
\text { among students previously eligible } \\
\text { for free or reduced-price meals } \\
(\mathrm{RR}=0.91,95 \% \mathrm{CI} 0.86,0.96) .\end{array}$ & Low \\
\hline $\begin{array}{l}\text { Ribar et al. } \\
2013 \text { [49] }\end{array}$ & $\begin{array}{l}\text { North Carolina; } \\
\text { elementary schools } \\
\text { that changed } \\
\text { between USBP and } \\
\text { mean-tested SBP } \\
(n=4 \text { schools }) \text { and } \\
\text { matched schools with } \\
\text { no change }(n=6)\end{array}$ & $\begin{array}{l}\text { QE: Pre/post } \\
\text { (with control) }\end{array}$ & $\begin{array}{l}2007-2008 \text { to } \\
2008-2009 \text { SY }\end{array}$ & USBP & $\begin{array}{l}\text { (1) Participation: Grades 1-5 } \\
\text { (2) Attendance: Grades 1-5 } \\
\text { (3) Academic Performance: } \\
\text { state standardized test scores } \\
\text { in math and reading (grades } \\
\text { 3-5) and science (grade 5), }\end{array}$ & $\begin{array}{l}\text { (1) USBP was associated with a } \\
16.4 \% \uparrow \text { in breakfast participation } \\
\text { overall }(p<0.05) \text {, with the greatest } \\
\text { increases among higher-income } \\
\text { students }(27.5 \% ; p<0.05) \text {. } \\
\text { (2) No association with attendance. } \\
\text { (3) No association with test scores. }\end{array}$ & Low \\
\hline
\end{tabular}


Table 1. Cont.

\begin{tabular}{|c|c|c|c|c|c|c|c|}
\hline Author, Year & $\begin{array}{c}\text { Location; } \\
\text { Participant } \\
\text { Characteristics }\end{array}$ & Study Design & Year(s) & $\begin{array}{l}\text { Universal Meal } \\
\text { Provision }\end{array}$ & Outcome Measure(s) & Results & Risk of Bias ${ }^{2}$ \\
\hline Rivas 1994 [55] & $\begin{array}{l}\text { Brownsville, Texas; } \\
\text { one school district } \\
\text { before and after } \\
\text { implementing } \\
\text { Provision } 2 \\
\end{array}$ & $\begin{array}{l}\text { QE: Pre/post (no } \\
\text { control) }\end{array}$ & 1993-1994 SY & Provision 2 & $\begin{array}{l}\text { (1) Participation } \\
\text { (2) } \underline{\text { Finances }}\end{array}$ & $\begin{array}{l}\text { (1) Provision } 2 \text { was associated with a } \\
16 \% \uparrow \text { in overall school meal } \\
\text { participation } \\
\text { (2) Provision } 2 \text { was associated with a } \\
5 \% \uparrow \text { in district food service revenue }\end{array}$ & $\begin{array}{l}\text { Very } \\
\text { High }\end{array}$ \\
\hline $\begin{array}{c}\text { Robinson } \\
1994 \text { [56] (GAO } \\
\text { Report) }\end{array}$ & $\begin{array}{l}\text { USA; } 3 \text { states with } \\
\text { four school districts } \\
\text { implementing the } \\
\text { USDA No-Fee School } \\
\text { Meal Pilot Program }\end{array}$ & $\begin{array}{l}\text { QE: Pre/post (no } \\
\text { control) }\end{array}$ & $\begin{array}{l}1990-1991 \text { to } \\
1992-1993 \text { SY }\end{array}$ & & $\begin{array}{l}\text { (1) Participation } \\
\text { (2) } \underline{\text { Finances }}\end{array}$ & $\begin{array}{l}\text { (1) Universal free meals was } \\
\text { associated with } \uparrow \text { participation }(10 \% \\
\text { pt for NSLP). } \\
\text { (2) Federal reimbursement increased } \\
\text { by } 33 \% \text { overall due to increased } \\
\text { student meal participation; districts } \\
\text { incurred reduced administrative costs. }\end{array}$ & Very High \\
\hline $\begin{array}{l}\text { Schwartz et al. } \\
2020 \text { [39] }\end{array}$ & $\begin{array}{l}\text { New York City, New } \\
\text { York; middle schools } \\
\text { with universal free } \\
\text { lunch through } \\
\text { Provision } 2 \text { (free } \\
\text { breakfast was } \\
\text { available in all } \\
\text { schools prior to the } \\
\text { start of the study) }\end{array}$ & $\begin{array}{l}\text { QE: Pre/post (no } \\
\text { control) }\end{array}$ & 2010-2013 & Provision 2 & $\begin{array}{l}\text { (1) Participation } \\
\text { (2) } \text { Attendance } \\
\text { (3) Academic Performance: } \\
\text { standardized test scores } \\
\text { (English Language Arts } \\
\text { [ELA] and math) } \\
\text { (4) BMI: objective } \\
\text { measurements by schools }\end{array}$ & $\begin{array}{l}\text { (1) Provision } 2 \text { was associated with } \uparrow \\
\text { school lunch participation ( } 5.39 \% \\
\text { among lower-income students } \\
\text { [ } p<0.01] \text { and } 10.97 \% \text { among higher } \\
\text { income students [ } p<0.05] \text { ). } \\
\text { (2) No association with attendance } \\
\text { (3) Provision } 2 \text { was associated with } \uparrow \\
\text { in math scores }(0.036 \text { SD; } p<0.01) \text { and } \\
\text { ELA scores ( } 0.030 \text { SD; } p<0.01) \text {, with } \\
\text { the greatest increases among } \\
\text { higher-income students }(0.083 \text { SD } \\
{[p<0.01] \text { in math and } 0.059 \text { SD }} \\
\text { [ } p<0.01] \text { for ELA). } \\
\text { (4) No association with BMI. In } \\
\text { sub-analyses, Provision } 2 \text { was } \\
\text { associated with a } 2.5 \% \text { reduced } \\
\text { probability ( } p<0.01) \text { of obesity among } \\
\text { higher-income students. }\end{array}$ & Low \\
\hline
\end{tabular}


Table 1. Cont.

\begin{tabular}{|c|c|c|c|c|c|c|c|}
\hline Author, Year & $\begin{array}{c}\text { Location; } \\
\text { Participant } \\
\text { Characteristics }\end{array}$ & Study Design & Year(s) & $\begin{array}{l}\text { Universal Meal } \\
\text { Provision }\end{array}$ & Outcome Measure(s) & Results & Risk of Bias $^{2}$ \\
\hline $\begin{array}{c}\text { Soldavini et al. } \\
2019 \text { [52] }\end{array}$ & $\begin{array}{l}\text { North Carolina; } 2285 \\
\text { public schools } \\
\text { (elementary, middle, } \\
\text { and high schools) } \\
\text { with varying SBP } \\
\text { models (including } \\
\text { USBP) }\end{array}$ & CS & 2017 & USBP & Participation & $\begin{array}{l}\text { USBP was positively associated with } \\
\text { the odds of student participation at } \\
\text { breakfast for all school levels, except } \\
\text { high school students who were } \\
\text { previously eligible for free or } \\
\text { reduced-price meals. }\end{array}$ & Low \\
\hline $\begin{array}{c}\text { Tan et al. } 2020 \\
\text { [60] }\end{array}$ & $\begin{array}{l}\text { USA; national data } \\
\text { from K- } 8 \text { schools } \\
\text { ( } 80 \text { CEP schools } \\
\text { [n=842 students] } \\
\text { and } 118 \text { non-CEP } \\
\text { schools }[n=1463 \\
\text { students]) }\end{array}$ & $\begin{array}{l}\text { QE: post-only } \\
\text { (with control) }\end{array}$ & 2013-2015 & CEP & $\underline{\text { Participation }}$ & $\begin{array}{l}\text { CEP was associated with } \uparrow \text { NSLP } \\
\text { participation among students near the } \\
\text { cutoff for free or reduced-price meals } \\
(11.7 \% \text { higher likelihood of } \\
\text { participation, } p=0.023 \text { ) and } \\
\text { higher-income students (eligible for } \\
\text { full- price) [18.5\% higher likelihood of } \\
\text { participation, } p<0.001] \text { compared } \\
\text { with students at schools not } \\
\text { participating in CEP. CEP was also } \\
\text { associated with } \uparrow \text { USBP participation } \\
\text { among higher-income students } \\
(19.6 \% ; p<0.05) \text {. }\end{array}$ & Low \\
\hline $\begin{array}{l}\text { Taylor et al. } \\
2020[95]\end{array}$ & $\begin{array}{l}\text { Vermont; } 116 \text { school } \\
\text { staff members (e.g., } \\
\text { principals, food } \\
\text { service staff, business } \\
\text { managers, and } \\
\text { nurses) from K-12 } \\
\text { schools throughout } \\
\text { the state with CEP }\end{array}$ & CS & 2017 & CEP & $\begin{array}{l}\text { (1) Academic performance: } \\
\text { staff perceptions (measured } \\
\text { using an online survey) } \\
\text { (2) Finances: staff } \\
\text { perceptions (measured using } \\
\text { an online survey) }\end{array}$ & $\begin{array}{l}\text { (1) Within CEP schools, a higher } \\
\text { percentage of school staff perceived } \\
\text { that free meals were associated with } \\
\text { improved academic performance } \\
\text { (64.4\% agreed vs. } 34.5 \% \text { disagreed) } \\
\text { and students were more ready to learn } \\
\text { (83.0\% agreed vs. } 14.8 \% \text { disagreed). } \\
\text { (2) Approximately half of participants } \\
\text { (52.4\%) perceived that school finances } \\
\text { had improved with CEP, but only } 44 \% \\
\text { perceived that the school meal } \\
\text { program deficit was reduced. }\end{array}$ & Very High \\
\hline
\end{tabular}


Table 1. Cont.

\begin{tabular}{|c|c|c|c|c|c|c|c|}
\hline Author, Year & $\begin{array}{c}\text { Location; } \\
\text { Participant } \\
\text { Characteristics }\end{array}$ & Study Design & Year(s) & $\begin{array}{l}\text { Universal Meal } \\
\text { Provision }\end{array}$ & Outcome Measure(s) & Results & Risk of Bias ${ }^{2}$ \\
\hline $\begin{array}{l}\text { Turner et al. } \\
2019 \text { [59] }\end{array}$ & $\begin{array}{l}\text { California; Public } \\
\text { schools throughout } \\
\text { the state with } \\
\text { varying school meal } \\
\text { provisions }\end{array}$ & $\begin{array}{l}\text { QE: Pre/post } \\
\text { (with control) }\end{array}$ & $\begin{array}{l}2013-2014 \text { to } \\
2016-2017 \text { SY }\end{array}$ & $\begin{array}{c}\text { CEP or Provision } \\
1,2, \text { or } 3\end{array}$ & $\underline{\text { Participation }}$ & $\begin{array}{l}\text { Universal free school meals was } \\
\text { associated with } \uparrow \text { lunch participation } \\
\text { (5.79\% pt increase) and } \uparrow \text { breakfast } \\
\text { participation ( } 3.48 \% \text { pt increase) }\end{array}$ & Low \\
\hline $\begin{array}{c}\text { Wahlstrom et al. } \\
1999 \text { [22] }\end{array}$ & $\begin{array}{c}\text { Minnesota; } \\
6 \text { elementary schools } \\
\text { piloting USBP and } \\
3 \text { control schools }\end{array}$ & $\begin{array}{l}\text { QE: Pre/post (no } \\
\text { control) }\end{array}$ & $\begin{array}{c}1993-1994 \text { to } \\
1996-1997\end{array}$ & USBP & $\begin{array}{l}\text { (1) Participation: students in } \\
\text { grades K-8 (varying by } \\
\text { school) } \\
\text { (2) Academic Performance: } \\
\text { standardized achievement } \\
\text { test scores (grades 3-6) }\end{array}$ & $\begin{array}{l}\text { (1) High school breakfast } \\
\text { participation rates were observed and } \\
\text { maintained in schools with USBP (no } \\
\text { statistical analyses conducted). } \\
\text { (2) A general increase in standardized } \\
\text { achievement test scores for math and } \\
\text { reading were observed (no statistical } \\
\text { analyses conducted). }\end{array}$ & Very High \\
\hline
\end{tabular}

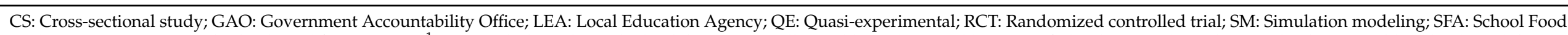

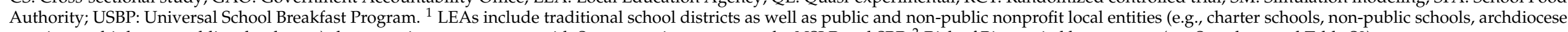
running multiple non-public schools, etc.) that enter into agree-ments with State agencies to operate the NSLP and SBP. ${ }^{2}$ Risk of Bias varied by outcome (see Supplemental Table S3) 
Table 2. Characteristics of studies conducted in other (non-U.S.) OECD countries included in the systematic review.

\begin{tabular}{|c|c|c|c|c|c|c|c|}
\hline Author, Year & $\begin{array}{c}\text { Location; } \\
\text { Participant } \\
\text { Characteristics }\end{array}$ & Study Design & Year(s) & $\begin{array}{l}\text { Universal Meal } \\
\text { Provision }\end{array}$ & Outcome Measure(s) & Results & Risk of Bias ${ }^{1}$ \\
\hline $\begin{array}{l}\text { Andersen et al. } \\
\text { 2014 [82] }\end{array}$ & $\begin{array}{l}\text { Denmark; } 9 \text { schools } \\
\text { ( } 3-4 \text { th grade } \\
\text { students) assigned to } \\
\text { free lunch ( } 3 \text { months) } \\
\text { and packed lunch } \\
\text { from home ( } 3 \\
\text { months); } n=834 \\
\text { students }\end{array}$ & $\begin{array}{l}\text { QE: Pre/post } \\
\text { (with control) }\end{array}$ & 2011-2012 SY & $\begin{array}{l}\text { Free school lunch } \\
\qquad(+ \text { snacks })\end{array}$ & $\begin{array}{l}\text { Diet: Foods and nutrients } \\
\text { consumed (measured using } \\
\text { a validated 7-day food } \\
\text { record tool } \\
\text { [self-administered] }\end{array}$ & $\begin{array}{l}\text { Free school lunches was associated } \\
\text { with improved diets, including } \\
\text { higher intakes of, vegetables }(16 \% \\
\text { higher intake; } p<0 \cdot 0001) \text { and fish } \\
(48 \% \text { higher; } p<0 \cdot 0001 \text {, which } \\
\text { resulted in higher intakes of vitamin } \\
\mathrm{D}(42 \% \text { higher; } p<0 \cdot 0001) \text { and } \\
\text { iodine }(11 \% \text { higher; } p<0 \cdot 0001) \text {. } \\
\text { Additionally, students consumed } \\
\text { significantly less saturated fat ( } 30 \% \\
\text { lower; } p<0 \cdot 0001) \text {. There were no } \\
\text { significant differences in total } \\
\text { calories. }\end{array}$ & Low \\
\hline $\begin{array}{l}\text { Asakura et al. } \\
2017 \text { [34] }\end{array}$ & $\begin{array}{l}\text { Japan; } 14 \text { elementary } \\
\text { schools ( } n=629 \\
\text { students) and } 13 \\
\text { junior high schools } \\
\text { ( } n=281 \text { students) }\end{array}$ & CS & 2014 & $\begin{array}{l}\text { Universal school } \\
\text { lunches }\end{array}$ & $\begin{array}{l}\text { Diet: Diet records completed } \\
\text { by parents / guardians on } \\
\text { three non-consecutive days } \\
\text { (two school days and one } \\
\text { weekend day) + plate waste } \\
\text { at school }\end{array}$ & $\begin{array}{l}\text { School lunches were positively } \\
\text { associated with total diet quality } \\
\text { (the prevalence of inadequate } \\
\text { nutrient intakes was higher on } \\
\text { weekend days compared with } \\
\text { school days for almost all of the } \\
\text { nutrients assessed). }\end{array}$ & High \\
\hline $\begin{array}{l}\text { Ask et al. } \\
2006[70]\end{array}$ & $\begin{array}{l}\text { Norway; } 10 \text { th grade } \\
\text { students in one } \\
\text { school with } 1 \\
\text { intervention } \\
\text { classroom with free } \\
\text { breakfasts for } 4 \\
\text { months ( } n=26 \\
\text { students) and } 1 \\
\text { control classroom } \\
\text { ( } n=28 \text { students) }\end{array}$ & $\begin{array}{l}\text { QE: Pre/post } \\
\text { (with control) }\end{array}$ & 2005 & $\begin{array}{c}\text { Pilot free } \\
\text { breakfast } \\
\text { intervention }\end{array}$ & $\begin{array}{c}\text { (1) Diet: Diet quality } \\
\text { (measured using a } \\
\text { non-validated FFQ, which } \\
\text { was used to calculate overall } \\
\text { HEI scores) } \\
\text { (2) BMI: objective } \\
\text { measurements by school } \\
\text { nurse }\end{array}$ & $\begin{array}{l}\text { (1) Free breakfast was positively } \\
\text { associated with overall HEI scores } \\
\text { among male students ( } 16 \text { pt increase } \\
\text { in HEI score; } p<0.05) \\
\text { (2) No changes in BMI were } \\
\text { observed among students with free } \\
\text { breakfast, but was significantly } \\
\text { higher among control students who } \\
\text { did not receive a school breakfast }\end{array}$ & Very High \\
\hline
\end{tabular}


Table 2. Cont.

\begin{tabular}{|c|c|c|c|c|c|c|c|}
\hline Author, Year & $\begin{array}{c}\text { Location; } \\
\text { Participant } \\
\text { Characteristics }\end{array}$ & Study Design & Year(s) & $\begin{array}{l}\text { Universal Meal } \\
\text { Provision }\end{array}$ & Outcome Measure(s) & Results & Risk of Bias ${ }^{1}$ \\
\hline $\begin{array}{l}\text { Ask et al. } \\
2010[74]\end{array}$ & $\begin{array}{l}\text { Norway; } 9 \text { th grade } \\
\quad \text { students } \\
\text { (1 intervention school } \\
\text { with free lunches for } \\
4 \text { months }[n=58 \\
\text { students] and } 1 \\
\text { control school }[n=92 \\
\text { students]) }\end{array}$ & $\begin{array}{l}\text { QE: Pre/post } \\
\text { (with control) }\end{array}$ & 2007 & $\begin{array}{l}\text { Pilot free lunch } \\
\text { intervention }\end{array}$ & $\begin{array}{l}\text { (1) Diet: Healthy food scores } \\
\text { (measured using a } \\
\text { non-validated FFQ, }) \\
\text { (2) BMI: objective } \\
\text { measurements by research } \\
\text { team }\end{array}$ & $\begin{array}{l}\text { (1) No association with food scores } \\
\text { (2) No association with BMI }\end{array}$ & Very High \\
\hline $\begin{array}{l}\text { Bartelink et al. } \\
\quad 2019 \text { [98] }\end{array}$ & $\begin{array}{l}\text { Netherlands; } 4 \\
\text { intervention and } 4 \\
\text { control schools } \\
\text { ( } n=1676 \text { children } \\
\text { age } 4-12 \text { years). }\end{array}$ & $\begin{array}{l}\text { QE: Pre/post } \\
\text { (with control) }\end{array}$ & 2015-2017 & $\begin{array}{c}\text { Free school lunch } \\
\text { (+ structured PA } \\
\text { after lunch) }\end{array}$ & $\begin{array}{l}\text { BMI: objective } \\
\text { measurements by research } \\
\text { team }\end{array}$ & $\begin{array}{l}\text { Free school lunch }(+\mathrm{PA}) \text { was } \\
\text { associated with } \downarrow \text { BMI z-score after } \\
\text { two years of follow-up } \\
\text { (standardized effect size }=-0.083 \\
p=0.01 \text { ) }\end{array}$ & Low \\
\hline $\begin{array}{c}\text { Dalma et al. } \\
2020 \text { [85] }\end{array}$ & $\begin{array}{c}\text { Greece; } 28 \\
\text { intervention }(n=1442 \\
\text { students) and } 23 \\
\text { control primary } \\
\text { schools ( } n=986 \\
\text { students) }\end{array}$ & Cluster RCT & 2014-2015 SY & $\begin{array}{l}\text { Free lunch } \\
\text { (+ nutrition } \\
\text { education) }\end{array}$ & $\begin{array}{l}\text { Diet: Food insecurity } \\
\text { (measured using the Food } \\
\text { Security Survey Module } \\
\text { [FSSM]; parent report) }\end{array}$ & $\begin{array}{l}\text { Free school lunch was associated } \\
\text { with } \downarrow \text { food insecurity (average } \\
\text { FSSM score decrease of } 0.31 \text { points; } \\
p=0.045 \text { ), with the greatest } \\
\text { reduction observed among food } \\
\text { insecure households with hunger } \\
\text { (average decrease of } 1.04 \text { points; } \\
p=0.023 \text { ). }\end{array}$ & Low \\
\hline $\begin{array}{l}\text { Gatenby } \\
2011[79]\end{array}$ & $\begin{array}{l}\text { England; two } \\
\text { primary schools (one } \\
\text { higher- and one } \\
\text { lower-income [147 } \\
\text { students ages } 8-11, \\
\text { and a subsample of } \\
n=20 \text { students with } \\
\text { food diaries]) }\end{array}$ & CS & 2004 & $\begin{array}{l}\text { Universal free } \\
\text { lunch }\end{array}$ & $\begin{array}{l}\text { Diet: Plate waste }+ \text { Food } \\
\text { diaries ( } 5 \text { days) and photos } \\
\text { taken by students }\end{array}$ & $\begin{array}{l}\text { Students who received school meals } \\
\text { consumed significantly less at lunch } \\
\text { on average compared with students } \\
\text { who brought meals from home. } \\
\text { However, due to compensation } \\
\text { outside of lunch, there were no } \\
\text { differences in overall nutrients } \\
\text { consumed throughout the day. }\end{array}$ & Very High \\
\hline
\end{tabular}


Table 2. Cont.

\begin{tabular}{|c|c|c|c|c|c|c|c|}
\hline Author, Year & $\begin{array}{c}\text { Location; } \\
\text { Participant } \\
\text { Characteristics }\end{array}$ & Study Design & Year(s) & $\begin{array}{l}\text { Universal Meal } \\
\text { Provision }\end{array}$ & Outcome Measure(s) & Results & Risk of Bias ${ }^{1}$ \\
\hline $\begin{array}{l}\text { Holford } \\
2015 \text { [63] }\end{array}$ & $\begin{array}{l}\text { Scotland; all primary } \\
\text { schools (students } \\
\text { ages } 4-11 \text { years) }\end{array}$ & $\begin{array}{l}\text { QE: Pre/post } \\
\text { (with control) }\end{array}$ & 2003-2013 & $\begin{array}{l}\text { Universal free } \\
\text { school lunch }\end{array}$ & Participation & $\begin{array}{l}\text { Universal free school lunch was } \\
\text { associated with an } \uparrow \text { on } \\
\text { participation among students } \\
\text { previously eligible for free school } \\
\text { meals }(3.3 \% \text { pt; } p<0.05 \text { ) as well as } \\
\text { among students not previously } \\
\text { eligible }(14.4 \% \text { pt; } p<0.001)\end{array}$ & Low \\
\hline $\begin{array}{l}\text { IlløKken et al. } \\
2017 \text { [75] }\end{array}$ & $\begin{array}{c}\text { Norway; one } \\
\text { intervention } \\
\text { elementary school } \\
\text { with students } \\
\text { receiving free school } \\
\text { lunch for six months } \\
\text { ( } n=55 \text { students) and } \\
\text { one control school } \\
\text { ( } n=109 \text { students); } \\
\text { students ages } \\
10-12 \text { years }\end{array}$ & $\begin{array}{l}\text { QE: Pre/post } \\
\text { (with control) }\end{array}$ & 2014-2015 SY & Free school lunch & $\begin{array}{l}\text { Diet: Healthy food scores } \\
\text { (measured using an FFQ) }\end{array}$ & $\begin{array}{l}\text { Free school lunch was associated } \\
\text { with } \uparrow \text { in healthy food scores } \\
\text { (change in total healthy food score } \\
\text { of } 1.7 \text { vs. } 0.5 ; p<0.01 \text { ), primarily } \\
\text { due to an increased frequency of } \\
\text { consuming fruits }(p<0.01 \text { ), } \\
\text { vegetables }(p<0.01) \text {, and fish } \\
\text { spread }(p=0.02) \text {. }\end{array}$ & High \\
\hline $\begin{array}{l}\text { Jenkins et al. } \\
2015 \text { [73] }\end{array}$ & $\begin{array}{l}\text { Wales; } 111 \text { primary } \\
\text { schools randomly } \\
\text { assigned to free } \\
\text { school breakfast } \\
(n=55 \text { schools) or } \\
\text { control (delayed } \\
\text { intervention }[n=56 \\
\text { schools]); students } \\
\text { ages } 9-11 \text { years }\end{array}$ & Cluster RCT & $\begin{array}{l}2004-2005 \text { to } \\
2006-2007 \text { SY }\end{array}$ & $\begin{array}{l}\text { Primary School } \\
\text { Free Breakfast } \\
\text { Initiative }\end{array}$ & Diet: $24-\mathrm{h}$ recalls & $\begin{array}{l}\text { There were no differences in the } \\
\text { nutritional quality of breakfasts } \\
\text { consumed at school or at home, } \\
\text { except significantly higher levels of } \\
\text { selenium ( } 5.1 \mu \mathrm{g} \text { vs. } 3.2 \mu \mathrm{g} ; p<0.01 \\
\text { and carbohydrates }(59.8 \mathrm{~g} \text { vs. } 48.7 \mathrm{~g} \text {; } \\
p<0.01) \text { in school meals. Among } \\
\text { students who ate a school breakfast, } \\
49 \% \text { had already consumed a } \\
\text { breakfast at home that morning, } \\
\text { although there were no significant } \\
\text { differences in caloric intake over a } \\
24 \text {-h period. }\end{array}$ & High \\
\hline
\end{tabular}


Table 2. Cont.

\begin{tabular}{|c|c|c|c|c|c|c|c|}
\hline Author, Year & $\begin{array}{c}\text { Location; } \\
\text { Participant } \\
\text { Characteristics } \\
\end{array}$ & Study Design & Year(s) & $\begin{array}{l}\text { Universal Meal } \\
\text { Provision }\end{array}$ & Outcome Measure(s) & Results & Risk of Bias ${ }^{1}$ \\
\hline $\begin{array}{l}\text { Laursen et al. } \\
2015 \text { [90] }\end{array}$ & $\begin{array}{l}\text { Denmark; } 9 \text { schools } \\
\text { (3-4th grade } \\
\text { students) assigned to } \\
\text { free lunch ( } 3 \text { months) } \\
\text { and packed lunch } \\
\text { from home } \\
\text { (3 months); } n=797 \\
\text { students }\end{array}$ & Cluster RCT & 2011-2012 SY & $\begin{array}{l}\text { Free school lunch } \\
\qquad(+ \text { snacks })\end{array}$ & Attendance & $\begin{array}{l}\text { No association with } \\
\text { attendance rates }\end{array}$ & Low \\
\hline $\begin{array}{l}\text { MacLardie et al. } \\
2008 \text { (Scottish } \\
\text { Govt } \\
\text { report) [62] }\end{array}$ & $\begin{array}{l}\text { Scotland; } 5 \text { local } \\
\text { authorities }\end{array}$ & $\begin{array}{l}\text { QE: Pre/post (no } \\
\text { control) }\end{array}$ & 2007-2008 SY & $\begin{array}{l}\text { Free school meals } \\
\text { trial for P1-P3 } \\
\text { pupils (universal } \\
\text { free lunch) }\end{array}$ & $\begin{array}{l}\text { (1) Participation } \\
\text { (2) Finances }\end{array}$ & $\begin{array}{l}\text { (1) An } \uparrow \text { in participation of } 22 \% \text { pts } \\
\text { was observed in schools with free } \\
\text { school lunches, with the greatest } \\
\text { increases among students not } \\
\text { previously registered for free school } \\
\text { meals ( } 28 \% \text { pts). An increase in } \\
\text { participation was also observed } \\
\text { among students previously eligible } \\
\text { for free school meals ( } 4 \% \\
\text { pt increase). } \\
\text { (2) The cost of implemented school } \\
\text { meals varied from } £ 1.79 \text { to } £ 4.65 \text { per } \\
\text { additional meal. Costs tended to be } \\
\text { lower in areas with a greater } \\
\text { number of additional meals served. }\end{array}$ & Very High \\
\hline
\end{tabular}


Table 2. Cont.

\begin{tabular}{|c|c|c|c|c|c|c|c|}
\hline Author, Year & $\begin{array}{c}\text { Location; } \\
\text { Participant } \\
\text { Characteristics }\end{array}$ & Study Design & Year(s) & $\begin{array}{c}\text { Universal Meal } \\
\text { Provision }\end{array}$ & Outcome Measure(s) & Results & Risk of Bias ${ }^{1}$ \\
\hline $\begin{array}{c}\text { Mhurchu et al. } \\
2012 \text { [84] }\end{array}$ & $\begin{array}{l}\text { New Zealand; } 14 \\
\text { primary schools with } \\
\text { staggered } \\
\text { implementation of } \\
\text { free school breakfasts } \\
\text { ( } n=424 \text { students } \\
\text { ages } 5-13 \text { years) }\end{array}$ & Cluster RCT & 2010 & $\begin{array}{c}\text { Free school } \\
\text { breakfast } \\
\text { program }\end{array}$ & $\begin{array}{l}\text { (1) Diet: Short-term hunger } \\
\text { (measured using satiety scale } \\
\text { for children [self-report]), } \\
\text { student breakfast habits } \\
\text { (parent-report), and } \\
\text { child/household food } \\
\text { security (measured using the } \\
\text { CCHIP Scale } \\
\text { [parent-report]). } \\
\text { (2) Attendance } \\
\text { (3) Academic Performance: } \\
\text { standardized tests of math } \\
\text { and literacy }\end{array}$ & $\begin{array}{l}\text { (1) Free school breakfast was } \\
\text { associated with a } \downarrow \text { in children's } \\
\text { self-reported short-term hunger } \\
\text { (increase of } 8.6 \text { units on the satiety } \\
\text { scale; } p=0.001 \text { ). No association } \\
\text { with child or household food } \\
\text { security, or breakfast frequency. } \\
\text { (2) No association with overall } \\
\text { attendance. In a sub-analysis } \\
\text { examining students who frequently } \\
\text { attended the SBP ( } \geq 50 \% \text { of the } \\
\text { time), free school breakfast was } \\
\text { associated with a } 1.6 \% \text { increase in } \\
\text { attendance ( } p=0.016 \text { ). } \\
\text { (3) No association with academic } \\
\text { performance }\end{array}$ & Low \\
\hline $\begin{array}{c}\text { Moore et al. } \\
2014 \text { [72] }\end{array}$ & $\begin{array}{l}\text { Wales; } 111 \text { primary } \\
\text { schools randomly } \\
\text { assigned to free } \\
\text { school breakfast } \\
(n=55 \text { schools) or } \\
\text { control (delayed } \\
\text { intervention }[n=56 \\
\text { schools]), students } \\
\text { ages } 9-11 \text { years }\end{array}$ & Cluster RCT & $\begin{array}{l}2004-2005 \text { to } \\
2006-2007 \text { SY }\end{array}$ & $\begin{array}{l}\text { Primary School } \\
\text { Free Breakfast } \\
\text { Initiative }\end{array}$ & $\begin{array}{l}\text { (1) Diet: healthy food } \\
\text { consumption and breakfast } \\
\text { skipping (measured using a } \\
\text { validated dietary recall } \\
\text { questionnaire) } \\
\text { (2) Academic Performance: } \\
\text { Cognitive tests administered } \\
\text { in classrooms }\end{array}$ & $\begin{array}{l}\text { (1) Free breakfast was associated } \\
\text { with an } \uparrow \text { in the number of healthy } \\
\text { items at breakfast }(0.25 \text { more } \\
\text { servings of healthy foods }[p<0.01]) \text {, } \\
\text { with greater improvements } \\
\text { observed in lower-income schools. } \\
\text { While there was no overall } \\
\text { association with breakfast skipping, } \\
\text { there was a significant reduction in } \\
\text { breakfast skipping among children } \\
\text { from lower-income schools and } \\
\text { households }(p<0.05) \text {. } \\
\text { (2) No association with } \\
\text { cognitive tests. }\end{array}$ & High \\
\hline
\end{tabular}


Table 2. Cont.

\begin{tabular}{|c|c|c|c|c|c|c|c|}
\hline Author, Year & $\begin{array}{c}\text { Location; } \\
\text { Participant } \\
\text { Characteristics }\end{array}$ & Study Design & Year(s) & $\begin{array}{l}\text { Universal Meal } \\
\text { Provision }\end{array}$ & Outcome Measure(s) & Results & Risk of Bias ${ }^{1}$ \\
\hline $\begin{array}{l}\text { Munday et al. } \\
2017 \text { [81] }\end{array}$ & $\begin{array}{l}\text { New Zealand; one } \\
\text { kindergarten class } \\
\text { ( } n=17 \text { students); } \\
2.5 \text { months of } \\
\text { exposure to } \\
\text { intervention }\end{array}$ & $\begin{array}{l}\text { QE: Pre/post (no } \\
\text { control) }\end{array}$ & 2014 & $\begin{array}{l}\text { Free lunches }+ \\
\text { educational } \\
\text { component }\end{array}$ & $\begin{array}{l}\text { (1) Diet: Foods and nutrients } \\
\text { consumed (measure using a } \\
\text { 24-h modified dietary recall } \\
\text { questionnaire data and a } \\
\text { vegetable- and fruit-specific } \\
\text { FFQ [teacher and } \\
\text { parent-report]) } \\
\text { (2) Attendance }\end{array}$ & $\begin{array}{l}\text { (1) Free lunch was associated with } \downarrow \\
\text { in snack food consumption at school } \\
\text { ( } p=0.015 \text { ). No association with } \\
\text { overall nutrients. } \\
\text { (2) No association with attendance. }\end{array}$ & Very High \\
\hline $\begin{array}{l}\text { Murphy et al. } \\
2011 \text { [71] }\end{array}$ & $\begin{array}{l}\text { Wales; } 111 \text { primary } \\
\text { schools randomly } \\
\text { assigned to free } \\
\text { school breakfast } \\
(n=55 \text { schools) or } \\
\text { control (delayed } \\
\text { intervention }[n=56 \\
\text { schools]), students } \\
\text { ages } 9-11 \text { years }\end{array}$ & Cluster RCT & $\begin{array}{l}2004-2005 \text { to } \\
2006-2007 \text { SY }\end{array}$ & $\begin{array}{l}\text { Primary School } \\
\text { Free Breakfast } \\
\text { Initiative }\end{array}$ & $\begin{array}{l}\text { (1) Diet: healthy food } \\
\text { consumption and breakfast } \\
\text { skipping (measured using a } \\
\text { validated dietary recall } \\
\text { questionnaire) } \\
\text { (2) Academic Performance: } \\
\text { Cognitive tests administered } \\
\text { in classrooms }\end{array}$ & $\begin{array}{l}\text { (1) Free breakfast was associated } \\
\text { with an } \uparrow \text { in the number of healthy } \\
\text { items at breakfast }(0.23 \text { more } \\
\text { servings of healthy foods }[p<0.01]) \text {, } \\
\text { with greater improvements } \\
\text { observed in lower-income schools. } \\
\text { No association with } \\
\text { breakfast skipping. } \\
\text { (2) No association with } \\
\text { cognitive tests. }\end{array}$ & High \\
\hline $\begin{array}{l}\text { Sabinsky et al. } \\
\text { 2018 [83] }\end{array}$ & $\begin{array}{l}\text { Denmark; } 4 \\
\text { intervention school } \\
\text { and } 4 \text { control schools } \\
(n=984 \text { students in } \\
\text { grades } 2-6 \text {; students } \\
\text { ages } 7-13 \text { years }\end{array}$ & $\begin{array}{l}\text { QE: Pre/post } \\
\text { (with control) }\end{array}$ & 2008 & $\begin{array}{l}\text { Free school } \\
\text { lunches }\end{array}$ & $\begin{array}{l}\text { Diet: Diet quality (measured } \\
\text { using digital photography } \\
\text { on } 3 \text { consecutive days + a } \\
\text { validated Meal Index of } \\
\text { dietary Quality (Meal IQ) }\end{array}$ & $\begin{array}{l}\text { Free meals were associated with } \uparrow \\
\text { dietary quality of the lunch eaten } \\
\text { compared with packed lunches } \\
(p=0.004) \text {, due in part to reductions } \\
\text { in saturated fat and snacks and } \\
\text { increases in vegetables and fish. } \\
\text { When the school meals were not } \\
\text { provided for free, selection of these } \\
\text { meals was limited and no difference } \\
\text { in dietary quality was observed. }\end{array}$ & Low \\
\hline
\end{tabular}


Table 2. Cont.

\begin{tabular}{|c|c|c|c|c|c|c|c|}
\hline Author, Year & $\begin{array}{c}\text { Location; } \\
\text { Participant } \\
\text { Characteristics }\end{array}$ & Study Design & Year(s) & $\begin{array}{l}\text { Universal Meal } \\
\text { Provision }\end{array}$ & Outcome Measure(s) & Results & Risk of Bias ${ }^{1}$ \\
\hline $\begin{array}{c}\text { Spence et al. } \\
2020[78]\end{array}$ & $\begin{array}{c}\text { England; Two } \\
\text { primary schools } \\
\text { (students age } \\
4-7 \text { years) before and } \\
\text { after implementation } \\
\text { of UIFSM }\end{array}$ & $\begin{array}{l}\text { QE: Pre/post } \\
\text { (no control) }\end{array}$ & $\begin{array}{l}\text { 2008-2009 SY and } \\
2017-2018 \text { SY }\end{array}$ & UIFSM & $\begin{array}{l}\text { Diet: Foods and nutrients } \\
\text { consumed (measuring using } \\
\text { a validated } 24 \text {-hr food diary } \\
\text { on four consecutive days) }\end{array}$ & $\begin{array}{l}\text { UIFSM was associated with } \downarrow \\
\text { consumption of non-milk extrinsic } \\
\text { sugar (i.e., added sugar [mean } \\
\text { change }-4.6 \%, p<0.001] \text { ) and } \\
\text { biscuits (i.e., shortbread cookies } \\
{[-0.4, p<0.001] \text { ) at lunch. The }} \\
\text { reductions in added sugar were } \\
\text { observed in students' overall diets } \\
\text { as well ( }-3.8 \%, p<0.001 \text { ). However, } \\
\text { an } \uparrow \text { in cakes } / \text { sweet puddings were } \\
\text { observed which were offered with } \\
\text { school lunches (after the main } \\
\text { meal) daily. }\end{array}$ & High \\
\hline $\begin{array}{c}\text { Petralia et al. } \\
2016 \text { [86] }\end{array}$ & $\begin{array}{l}\text { Greece; } 162 \text { schools } \\
\text { provided with free } \\
\text { lunches (primary and } \\
\text { secondary schools) }\end{array}$ & $\begin{array}{l}\text { QE: Pre/post } \\
\text { (no control) }\end{array}$ & 2012-2013 SY & $\begin{array}{l}\text { Free lunch } \\
\text { (+ nutrition } \\
\text { education) }\end{array}$ & $\begin{array}{l}\text { Diet: Food insecurity } \\
\text { (measured using the Food } \\
\text { Security Survey Module } \\
\text { [FSSM]; parent report) }\end{array}$ & $\begin{array}{l}\text { Free school lunch was associated } \\
\text { with } \downarrow \text { food insecurity (decrease } \\
\text { from } 64.2 \% \text { of households with food } \\
\text { insecurity to } 59.1 \% ; p<0.001 \text { ). The } \\
\text { greatest reductions were observed } \\
\text { among food insecure households } \\
\text { with hunger; each additional month } \\
\text { of free school meals was associated } \\
\text { with a } 13 \% \text { increase in the odds of } \\
\text { not reporting hunger problems (OR } \\
1.13,95 \% \text { CI } 1.02-1.25 \text { ). }\end{array}$ & High \\
\hline
\end{tabular}


Table 2. Cont.

\begin{tabular}{|c|c|c|c|c|c|c|c|}
\hline Author, Year & $\begin{array}{c}\text { Location; } \\
\text { Participant } \\
\text { Characteristics }\end{array}$ & Study Design & Year(s) & $\begin{array}{l}\text { Universal Meal } \\
\text { Provision }\end{array}$ & Outcome Measure(s) & Results & Risk of Bias $^{1}$ \\
\hline $\begin{array}{l}\text { Vik et al. } 2019 \\
\text { (BMC Public } \\
\text { Health) [76] }\end{array}$ & $\begin{array}{c}\text { Norway; one } \\
\text { intervention } \\
\text { elementary school } \\
\text { with students } \\
\text { receiving free school } \\
\text { lunch for one year } \\
\text { ( } n=55 \text { students) and } \\
\text { one control school } \\
\text { ( } n=109 \text { students); } \\
\text { students ages } \\
10-12 \text { years }\end{array}$ & $\begin{array}{l}\text { QE: Pre/post } \\
\text { (with control) }\end{array}$ & 2014-2015 SY & $\begin{array}{l}\text { Free School } \\
\text { Lunches }\end{array}$ & $\begin{array}{l}\text { (1) Diet: Diet quality } \\
\text { (measured using validated } \\
\text { FFQs, with results used to } \\
\text { calculate healthy food scores) } \\
\text { (2) BMI: objectively } \\
\text { measured at school }\end{array}$ & $\begin{array}{l}\text { (1) Free school lunches were } \\
\text { associated with } \uparrow \text { healthy food } \\
\text { scores }(\mathrm{F}=10.941, p=0.001) \text { after } \\
\text { one year of exposure, with the } \\
\text { greatest increases among lower-SES } \\
\text { students. } \\
\text { (2) Free school lunches were } \\
\text { associated with } \uparrow \text { BMI z-scores } \\
(\mathrm{F}=10.007, p=0.002) \text { after one year } \\
\text { of exposure. }\end{array}$ & Low \\
\hline $\begin{array}{l}\text { Vik et al. } 2019 \\
\text { (BMC Res } \\
\text { Notes) [77] }\end{array}$ & $\begin{array}{c}\text { Norway; one } \\
\text { intervention } \\
\text { elementary school } \\
\text { with students } \\
\text { receiving free school } \\
\text { lunch for one year } \\
\text { ( } n=55 \text { students) and } \\
\text { one control school } \\
\text { ( } n=109 \text { students); } \\
\text { students ages } \\
10-12 \text { years }\end{array}$ & $\begin{array}{l}\text { QE: Pre/post } \\
\text { (with control) }\end{array}$ & 2014-2015 SY & $\begin{array}{l}\text { Free School } \\
\text { Lunches }\end{array}$ & $\begin{array}{c}\text { Diet: Frequency of } \\
\text { consuming meals (measured } \\
\text { using a validated } \\
\text { questionnaire) }\end{array}$ & $\begin{array}{l}\text { There was no association between } \\
\text { free school meals and meal } \\
\text { frequency after } 1 \text { year of exposure. }\end{array}$ & Low \\
\hline $\begin{array}{l}\text { Yamaguchi et al. } \\
2018 \text { [80] }\end{array}$ & $\begin{array}{c}\text { Japan; Four } \\
\text { municipalities, } \\
n=719 \text { elementary } \\
\text { school children (ages } \\
\text { 6-12 years). }\end{array}$ & CS & 2013 & $\begin{array}{l}\text { Universal school } \\
\text { lunch }\end{array}$ & $\begin{array}{l}\text { Diet: dietary habits } \\
\text { (measured using the } \\
\text { validated brief diet history } \\
\text { questionnaire-10 years old } \\
\text { [BDHQ-10]; } \\
\text { self-administered) }\end{array}$ & $\begin{array}{l}\text { Universal school lunches were } \\
\text { associated with a reduction in } \\
\text { SES-related disparities in children's } \\
\text { diets (a reduction in the inequality } \\
\text { of vegetable intake by } 9.9 \% \text { and fruit } \\
\text { intake by } 3.4 \% \text { ) }\end{array}$ & Low \\
\hline
\end{tabular}

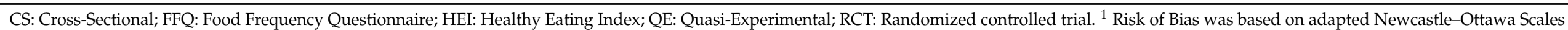
(NOS) for cross-sectional and cohort studies (Supplemental Tables S1 and S2). 


\section{Discussion}

To our knowledge, this is the first international systematic review of the literature on universal free school meals. This evidence-based review examined the impact of universal free school meals on multiple outcomes for children and schools: (a) meal participation, (b) children's diet quality and food insecurity, (c) academic performance, (d) attendance, (e) BMI, and (f) school finances. This review found substantial support for a positive association between providing universal free school meals and increased meal participation rates. The current review also found evidence for improvements in diet quality and academic performance when universal free school meal provisions included lunch, whereas the evidence was mixed when only universal free breakfasts were available. Research examining the effect of universal free meals on student attendance was mixed; some studies found that overall attendance improved, while others documented significant improvements specifically among higher-risk populations (e.g., lower-income and/or food insecure). The limited studies examining food security also suggested that universal free school meal provisions were associated with improved food security. Nearly all studies found no adverse associations with BMI. The research examining school finances also suggested that schools in the U.S. with a high percentage of students from low-income households may benefit financially from CEP. Overall, the preponderance of the evidence associates positive outcomes with universal free school meals, particularly provisions that include lunch. These findings outweigh the few studies that raised concerns about possible adverse outcomes.

This literature review found that providing universal free school meals was consistently associated with significant increases in school meal participation. Although increases were generally observed among students previously eligible for free meals $[39,48,52,57,61]$, the largest increases in participation were observed among students not previously eligible for free or reduced-price school meals $[39,48,52,58,60,61]$. This pattern likely reflects the fact that participation rates are usually lower among students who do not qualify for free or reduced-price school meals, thus providing a greater opportunity for an increase. These findings have several important implications for students. First, the increases in participation among students who were previously eligible for free meals but were not participating suggests that policies to provide universal free school meals may reduce stigma associated with receiving school meals, which can result in more low-income children receiving healthy meals and further reducing food insecurity among a vulnerable population. Prior research has also indicated that universal free school meal policies may be successful by reducing stigma $[22,99,100]$. Additionally, when universal free school meals are provided, they reach students who may have been eligible based on income but not enrolled for free/reduced price meals. Failure to sign up for free or reduced-price meals may occur due to social stigma, a lack of information, or challenges with enrolling. Universal free meals also reach students who come from households with food insecurity, but which are not eligible for reduced-priced meals due to family incomes slightly above the eligibility threshold (185\% of the federal poverty level) [88,101-103].

Among the studies examining universal free school lunches (with or without breakfast), positive associations were generally observed with students' diet quality and academic performance, particularly in the presence of strong nutrition standards that include fruits, vegetables, and/or whole grains. These findings highlight the importance of healthy meal guidelines for schools. Additionally, a government report examining universal free school meals noted that due to the reduction in time spent processing applications for free and reduced-price meals, cafeteria staff time was redirected to improving meal quality, nutrition education, and staff development, which can further the positive influence on students' dietary behaviors [56]. The limited research examining food security was encouraging, but more high-quality studies are needed to examine if universal free school meals improve food security among students and families. Research has also found that universal free school meals is associated with reductions in students' behavioral incidents (e.g., fights) and suspensions, which can interfere with academic performance [38,104,105]. 
Accordingly, investing in universal free school meal programs may have a profound impact on children's overall health and wellbeing.

In several domains, the results were consistently positive when examining provisions that included universal free lunches, but were mixed when examining schools that only provided universal free breakfasts. The lack of changes observed with universal free breakfast alone may be in part due to the generally low breakfast participation rates observed, despite being universally free. Emerging research examining breakfast in the classroom models suggests that this method of implementing free breakfasts may substantially increase its reach to children [106-108]. Future research should examine whether there are additional benefits when children have access to both universal free breakfast in the classroom and universal free lunches.

While research examining the association between universal free school meals and attendance was mixed, this might partially be explained by the short exposure to universal free school meals in several of the studies. For example, Bartfeld et al. found that no associations with attendance during the first year of implementing CEP, but low attendance rates were significantly reduced after two years of exposure [89]. This may also partially explain why no significant associations were observed among the studies conducted outside of the U.S., which had exposures to free school meals of $\leq 10$ months. Additionally, several studies found that the improvements were only observed among subpopulations, particularly lower-income and/or food insecure students $[48,67,89]$. This may have important implications for reducing socioeconomic disparities and more long-term studies are warranted.

Despite concerns about the impact of universal free school meals on BMI, nearly all the studies (6 out of 7) examining BMI found no detrimental impact in terms of increased prevalence of obesity, and in fact, several found a potential reduction in obesity risk associated with universal free meals. This corresponds with several other working papers examining universal free school meals in both U.S. and other OECD countries (i.e., England and Sweden), as well as with peer-reviewed studies examining breakfast in the classroom initiatives and participation in school meal programs more broadly (i.e., means-tested), which have found inverse or no associations with BMI [96,106,109-112]. For example, Holford and Rabe at the Institute for Social and Economic Research examined UIFSM and found that children receiving free school lunches for a year were $1.2 \%$ more likely to be a healthy weight and $0.7 \%$ less likely to be obese [111]. Overall, research examining universal free school meals and BMI suggests that in the presence of strong meal standards, providing universal free school meals to students appears to have no adverse impacts on weight and in fact, may reduce the risk of obesity among some populations, although more peer-reviewed research in the U.S. and other countries is warranted.

School finances were also examined in a limited number of studies, primarily in the U.S. While these studies generally found that school food service budgets may have benefitted from CEP, selection bias may have been an issue. The federal reimbursement rate corresponds to the percentage of students categorically eligible for free meals (the "identified student percentage" [ISP]); therefore, ISP is highly correlated with school/district participation in CEP because schools with a high ISP are more likely to participate and will also have higher federal reimbursement rates [113]. For example, with the current federal reimbursement calculation (which multiplies the ISP by 1.6 to calculate the percentage of meals that will be reimbursed at the rate for free meals), a school with a $40 \%$ ISP would receive federal reimbursement that would only cover $64 \%$ of all the meals served. Schools actually need an ISP of $\geq 62.5 \%$ in order to be fully reimbursed by the federal government for school meals served with CEP. A policy change to cease the use of ISP and instead fully reimburse schools for all meals served using a national universal free school meal schema would alleviate concerns regarding financial losses to schools. Two additional challenges to school food service finances are that the price charged for full-price meals does not always cover the full cost of the school meal, and that some families fail to pay for the full or reduced-price meals received by their children, resulting in school meal 
debt. Universal free school meals can help address these issues by shifting the burden of covering school meal costs away from schools and families. In England, the UIFSM was estimated to cost $£ 400$ per student annually (roughly USD 550/student) [114]. However, prior research has suggested that universal free school meals may have a positive impact on household finances, particularly among lower income families (many of whom are still above the threshold to qualify for free or reduced-price meals) $[115,116]$. One study in UK that conducted financial modeling analyses found that families who were in the second and third lowest deciles of income (who were not already eligible for free school meals) benefited the most from universal free school meals [115]. Reducing food insecurity through universal free meals may also help alleviate its concomitant societal costs. For example, in the U.S., food insecurity has been estimated to be associated with over USD 1.2 billion in costs to the health care and education systems [117]. Overall, more research examining the total cost of universal free school meals at the national level is warranted, and this research should account for potential direct and indirect benefits of universal free school meals that may have both short and long-term economic benefits.

Several studies examined differences in outcomes related to universal free school meals by student socio-economic status. Interestingly, many studies found that not only did universal free school meals tend to be associated with positive outcomes among lowerincome students- the population that is typically targeted by free school meal programsbut higher-income students frequently benefitted as well. For example, higher school meal participation rates were observed among children from both higher and lower-income households in the majority of included studies, and multiple studies found that attendance improved among both lower-income and higher-income populations $[48,87,89]$. Similarly, two studies found positive associations with academic performance among both lower and higher income students and one found a reduced probability of obesity among higher income students $[39,87]$. Prior research has also documented improvements in students diets after implementation of stronger school meal standards, including among both lower and higher-income students $[25,64,118]$. This may be in part because many students who are just above eligibility cutoffs (and do not qualify for free or reduced-price meals) also experience food insecurity and therefore may benefit from universal free school meals [119]. Overall, this suggests that universal free school meals may benefit socio-economically diverse student populations and countries that currently limit free school meals to lowerincome school districts may want to consider broader policies.

This study has several limitations. First, the assessment of outcomes varied from one study to another, especially regarding the evaluations of children's' diets. For example, while some studies used 24-h recalls, others used food frequency questionnaires or food insecurity questionnaires, and dietary assessments also varied in who completed them (e.g., student self-report or parent-report). While these methods have typically been validated, due to the heterogeneity in outcome measures, a meta-analysis was not possible. The risk of bias also varied from very high to low based on NOS scores, and the results of this review must be interpreted accordingly. However, when examining only the studies with a low risk of bias, the conclusions remained unchanged. Publication bias (i.e., studies with non-significant results are less likely to be published) may have also been an issue, although multiple studies included in the review found no significant associations. The studies reviewed were also conducted in economically developed countries; therefore, future systematic reviews should examine economically less-developed countries, especially as these results suggest that the most vulnerable populations (e.g., food insecure) incur the most benefit from universal free school meals. Lastly, while some studies were randomized, many of relied on natural experiments and therefore schools (and students) were not randomly assigned to receive free meals. However, natural experiments may have better external generalizability due to their implementation in real-world settings. Countries that are considering expanded universal free school meal programs could facilitate evaluations in diverse schools (including those that vary by student SES) through first enabling rigorous designs such as randomized trials before implementation on a wider scale. Such a phased 
roll-out would enable a fuller understanding of the impact of universal school meals on diverse student populations and school finances. This systematic review was further strengthened by the large number of studies included.

\section{Conclusions}

Overall, this review suggests that universal free school meals benefit students, particularly those who are food-insecure and/or near eligible for free meals in existing meanstested school meal models. The majority of studies in the current review found that universal free school meals were associated with increases in participation and improved diet quality and food security, and conversely, were associated with either no change or improved BMI. Further research is needed regarding the implementation of universal free meal programs and the ways in which optimal participation and benefits can be achieved through such policy changes. In the presence of strong nutrition guidelines, universal free school meals have multiple potential benefits for students and schools, and should be considered by countries not currently with this policy.

Supplementary Materials: The following are available online at https:/ / www.mdpi.com/2072-664 3/13/3/911/s1. Table S1: Summary of School Meal Provisions in the United States, Table S2: Quality Assessment for Cross-Sectional Studies based on the Newcastle Ottawa Quality Assessment Form, Table S3: Quality Assessment of Cohort and Quasi-experimental Studies based on the Newcastle Ottawa Quality Assessment Form.

Author Contributions: Conceptualization, J.F.W.C. and M.B.S.; Methodology, J.F.W.C., M.B.S., A.A.H., G.M.M., and L.T.; Data Curation, J.F.W.C., A.A.H., G.M.M.; Writing-Original Draft Preparation, J.F.W.C.; Writing—Review and Editing, J.F.W.C., M.B.S., A.A.H., G.M.M., and L.T. All authors have read and agreed to the published version of the manuscript.

Funding: This paper was supported by Healthy Eating Research, a national program of the Robert Wood Johnson Foundation.

Acknowledgments: The authors would like to thank the Healthy Eating Research staff at Duke University for their support.

Conflicts of Interest: The authors declare no conflict of interest.

\section{References}

1. World Health Organization. Food and Nutrition Policy for Schools: A Tool for the Development of School Nutrition Programmes in the European Region; WHO Regional Office for Europe: Copenhagen, Denmark, 2006.

2. Dooris, M.; Poland, B.; Kolbe, L.; De Leeuw, E.; McCall, D.S.; Wharf-Higgins, J. Healthy settings. In Global Perspectives on Health Promotion Effectiveness; Springer: Berlin/Heidelberg, Germany, 2007; pp. 327-352.

3. Langford, R.; Bonell, C.P.; Jones, H.E.; Pouliou, T.; Murphy, S.M.; Waters, E.; Komro, K.A.; Gibbs, L.F.; Magnus, D.; Campbell, R. The WHO Health Promoting School framework for improving the health and well-being of students and their academic achievement. Cochrane Database Syst. Rev. 2014. [CrossRef]

4. Mikkilä, V.; Räsänen, L.; Raitakari, O.; Pietinen, P.; Viikari, J. Consistent dietary patterns identified from childhood to adulthood: The cardiovascular risk in Young Finns Study. Br. J. Nutr. 2005, 93, 923-931. [CrossRef]

5. Movassagh, E.Z.; Baxter-Jones, A.D.; Kontulainen, S.; Whiting, S.J.; Vatanparast, H. Tracking dietary patterns over 20 years from childhood through adolescence into young adulthood: The Saskatchewan Pediatric Bone Mineral Accrual Study. Nutrients 2017, 9, 990. [CrossRef]

6. Whitaker, R.C.; Wright, J.A.; Pepe, M.S.; Seidel, K.D.; Dietz, W.H. Predicting obesity in young adulthood from childhood and parental obesity. N. Engl. J. Med. 1997, 337, 869-873. [CrossRef]

7. Lytle, L.A.; Seifert, S.; Greenstein, J.; McGovern, P. How do children's eating patterns and food choices change over time? Results from a cohort study. Am. J. Health Promot. 2000, 14, 222-228. [CrossRef]

8. United States Department of Agriculture. National School Lunch Program and School Breakfast Program: Nutrition Standards for All Foods Sold in School as Required by the Healthy, Hunger-Free Kids Act of 2010. Fed. Regist. 2016, 81, 50131-50151.

9. National Institute for Educational Policy Research; School Lunch Program in Japan; Kobe Institute: Kobe, Japan, 2003.

10. The Education (Nutritional Standards and Requirements for School Food) (England) (Amendment) Regulations 2008. Available online: https:/ / www.legislation.gov.uk/uksi/2008/1800/made (accessed on 1 March 2020).

11. The National Assembly of the Republic of Korea. Enforcement Rule of the School Meals Act. 2009. Available online: http: / /likms.Assembly.go.kr/law/jsp/main.jsp (accessed on 1 March 2020). 
12. The Secretary of State for Education, England. The Requirements for School Food Regulations 2014. 2014. Available online: https:/ / www.legislation.gov.uk/uksi/2014/1603/pdfs/uksi_20141603_en.pdf (accessed on 1 March 2020).

13. The Secretary of State for Children, Schools, and Families, England. The Education Act (2008) The Education (Nutritional Standards and Requirements for School Food) (England) (Amendment) Regulations 2008. 2008. Available online: https: //www.legislation.gov.uk/uksi/2008/1800/made (accessed on 1 March 2020).

14. Kim, M.; Abe, S.; Zhang, C.; Kim, S.; Choi, J.; Hernandez, M.; Nozue, M.; Yoon, J. Comparison of the nutrient-based standards for school lunches among South Korea, Japan, and Taiwan. Asia Pac. J. Clin. Nutr. 2017, 26, 160. [PubMed]

15. Juniusdottir, R.; Hörnell, A.; Gunnarsdottir, I.; Lagstrom, H.; Waling, M.; Olsson, C.; Talvia, S.; Olafsdottir, A.S. Composition of school meals in Sweden, Finland, and Iceland: Official guidelines and comparison with practice and availability. J. School Health 2018, 88, 744-753. [CrossRef]

16. McGuire, S. Institute of Medicine. Accelerating Progress in Obesity Prevention: Solving the Weight of the Nation; The National Academies Press: Washington, DC, USA; Oxford University Press: Washington, DC, USA, 2012.

17. Cohen, J.F.; Gorski, M.T.; Gruber, S.; Kurdziel, L.; Rimm, E.B. The effect of healthy dietary consumption on executive cognitive functioning in children and adolescents: A systematic review. Br. J. Nutr. 2016, 116, 989-1000. [CrossRef] [PubMed]

18. World Health Organization. Diet, Nutrition, and the Prevention of Chronic Diseases: Report of a Joint WHO/FAO Expert Consultation; World Health Organization: Geneva, Switzerland, 2003; Volume 916.

19. Gross, S.M.; Kelley, T.L.; Augustyn, M.; Wilson, M.J.; Bassarab, K.; Palmer, A. Household Food Security Status of Families with Children Attending Schools that Participate in the Community Eligibility Provision (CEP) and Those with Children Attending Schools that are CEP-Eligible, but Not Participating. J. Hunger Environ. Nutr. 2019, 1-16. [CrossRef]

20. Beaton, M.; Craig, P.; Katikireddi, S.; Jepson, R.; Williams, A. Evaluability assessment of free school meals for all children in P1 to P3. Proj. Rep. NHS Health Scotl. Edinb. 2014. [CrossRef]

21. Poppendieck, J. Free for All: Fixing School Food in America; Univ of California Press: Berkeley, CA, USA, 2011 ; Volume 28.

22. Wahlstrom, K.L.; Begalle, M.S. More than test scores: Results of the Universal School Breakfast Pilot in Minnesota. Top. Clin. Nutr. 1999, 15, 17-29. [CrossRef]

23. Cullen, K.W.; Chen, T.-A. The contribution of the USDA school breakfast and lunch program meals to student daily dietary intake. Prev. Med. Rep. 2017, 5, 82-85. [CrossRef] [PubMed]

24. Gearan, E.; Fox, M.K.; Niland, K.; Dotter, D.; Washburn, L.; Connor, P.; Olsho, L.; Wommack, T. School Nutrition and Meal Cost Study Final Report Volume 2: Nutritional Characteristics of School Meals. Math. Policy Res. 2019. Available online: https:/ / fns-prod.azureedge.net/sites/default/ files/resource-files/SNMCS-Volume2.pdf (accessed on 1 March 2020).

25. Fox, M.K.; Gearan, E.; Cabili, C.; Dotter, D.; Niland, K.; Washburn, L.; Paxton, N.; Olsho, L.; LeClair, L.; Tran, V. School Nutrition and Meal Cost Study Final Report Volume 4: Student Participation, Satisfaction, Plate Waste, and Dietary Intakes. Math. Policy Res. 2019. Available online: https://fns-prod.azureedge.net/sites/default/files/resource-files/SNMCS-Volume4.pdf (accessed on 1 March 2020).

26. Au, L.E.; Rosen, N.J.; Fenton, K.; Hecht, K.; Ritchie, L.D. Eating school lunch is associated with higher diet quality among elementary school students. J. Acad. Nutr. Diet. 2016, 116, 1817-1824. [CrossRef]

27. Farris, A.R.; Misyak, S.; Duffey, K.J.; Davis, G.C.; Hosig, K.; Atzaba-Poria, N.; McFerren, M.M.; Serrano, E.L. Nutritional comparison of packed and school lunches in pre-kindergarten and kindergarten children following the implementation of the 2012-2013 national school lunch program standards. J. Nutr. Educ. Behav. 2014, 46, 621-626. [CrossRef]

28. Au, L.E.; Gurzo, K.; Gosliner, W.; Webb, K.L.; Crawford, P.B.; Ritchie, L.D. Eating school meals daily is associated with healthier dietary intakes: The Healthy Communities Study. J. Acad. Nutri. Diet. 2018, 118, 1474-1481.e1471. [CrossRef]

29. Pellikka, K.; Manninen, M.; Taivalmaa, S. School Meals for All. School Feeding: Investment in Effective Learning-Case Finland; Viitattu 25.8. 2019; Ministry for Foreign Affairs of Finland: Helsinki, Finland; Finnish National Agency for Education: Helsinki, Finland, 2019.

30. European Commission. School Food Policy Fact Sheets; Sweden, 2013. Available online: https://ec.europa.eu/jrc/sites/jrcsh/ files/jrc-school-food-policy-factsheet-sweden_en.pdf (accessed on 1 August 2020).

31. Gaddis, J.E.; Jeon, J. Sustainability transitions in agri-food systems: Insights from South Korea's universal free, eco-friendly school lunch program. Agric. Hum. Values 2020, 37, 1055-1071. [CrossRef]

32. Scottish Government. Maternal and Child Health: Free School Meals. Available online: https://www.gov.scot/policies/maternaland-child-health/free-school-meals / (accessed on 1 August 2020).

33. Ishida, H. The history, current status, and future directions of the school lunch program in Japan. Jpn. J. Nutr. Diet. 2018, 76, S2-S11. [CrossRef]

34. Asakura, K.; Sasaki, S. School lunches in Japan: Their contribution to healthier nutrient intake among elementary-school and junior high-school children. Public Health Nutr. 2017, 20, 1523-1533. [CrossRef] [PubMed]

35. Levin, M.; Neuberger, Z. A guide to implementing community eligibility. Food Res. Action Center Cent. Budg. Policy Priorities Oct. 2013, 1. Available online: https:// citeseerx.ist.psu.edu/viewdoc/download?doi=10.1.1.397.1428\&rep=rep1\&type=pdf (accessed on 5 March 2020).

36. Food Research and Action Center (FRAC). Community Eligibility Report 2020; Food Research and Action Center (FRAC): Washington, DC, USA, 2020; Available online: https:/ / frac.org/cep-report-2020 (accessed on 1 August 2020). 
37. Logan, C.W. Community Eligibility Provision Evaluation; United States Department of Agriculture, Food and Nutrition Service, Office: Denver, CO, USA, 2014.

38. Altindag, D.T.; Baek, D.; Lee, H.; Merkle, J. Free lunch for all? The impact of universal school lunch on student misbehavior. Econ. Educ. Rev. 2020, 74, 101945. [CrossRef]

39. Schwartz, A.E.; Rothbart, M.W. Let them eat lunch: The impact of universal free meals on student performance. J. Policy Anal. Manag. 2020, 39, 376-410. [CrossRef]

40. Hecht, A.A.; Pollack Porter, K.M.; Turner, L. Impact of The Community Eligibility Provision of the Healthy, Hunger-Free Kids Act on Student Nutrition, Behavior, and Academic Outcomes: 2011-2019. Am. J. Public Health 2020, 110, 1405-1410. [CrossRef]

41. Moher, D.; Liberati, A.; Tetzlaff, J.; Altman, D.G.; Group, P. Preferred reporting items for systematic reviews and meta-analyses: The PRISMA statement. PLoS Med. 2009, 6, e1000097. [CrossRef]

42. PROSPERO International Prospective Register of Systematic Reviews. Available online: https://www.crd.york.ac.uk/prospero/ (accessed on 1 August 2020).

43. Organization for Economic Co-Operation and Development (OECD). List of OECD Member countries.

44. Wells, G.A.; Shea, B.; O'Connell, D.A.; Peterson, J.; Welch, V.; Losos, M.; Tugwell, P. The Newcastle-Ottawa Scale (NOS) for Assessing the Quality of Nonrandomised Studies in Meta-Analyses. 2000. Available online: http://www.ohri.ca/programs/ clinical_epidemiology / oxford.asp (accessed on 1 August 2020).

45. Wells, G.; Shea, B.; O'Connell, D.; Peterson, J.; Welch, V.; Losos, M.; Tugwell, P. Newcastle-Ottawa Quality Assessment Scale Cohort Studies; University of Ottawa: Ottawa, ON, Canada, 2014.

46. Luchini, C.; Stubbs, B.; Solmi, M.; Veronese, N. Assessing the quality of studies in meta-analyses: Advantages and limitations of the Newcastle Ottawa Scale. World J. Meta-Anal. 2017, 5, 80-84. [CrossRef]

47. Lo, C.K.-L.; Mertz, D.; Loeb, M. Newcastle-Ottawa Scale: Comparing reviewers' to authors' assessments. BMC Med. Res. Methodol. 2014, 14, 45. [CrossRef]

48. Leos-Urbel, J.; Schwartz, A.E.; Weinstein, M.; Corcoran, S. Not just for poor kids: The impact of universal free school breakfast on meal participation and student outcomes. Econ. Educ. Rev. 2013, 36, 88-107. [CrossRef]

49. Ribar, D.C.; Haldeman, L.A. Changes in meal participation, attendance, and test scores associated with the availability of universal free school breakfasts. Soc. Serv. Rev. 2013, 87, 354-385. [CrossRef]

50. McLaughlin, J.E.; Bernstein, L.S.; Crepinsek, M.K.; Daft, L.M.; Murphy, J.M. Evaluation of the School Breakfast Program Pilot Project: Findings from the First Year of Implementation. Food and Nutrition Services, USDA. 2002. Available online: https: / / files.eric.ed.gov / fulltext/ED481251.pdf (accessed on 1 August 2020).

51. Bernstein, L.S.; McLaughlin, J.E.; Crepinsek, M.K.; Daft, L.M. Evaluation of the School Breakfast Program Pilot Project: Final Report. Special Nutrition Programs. Report Number CN-04-SBP; Nutrition Assistance Program Report Series; US Department of Agriculture: Honolulu, HI, USA, 2004.

52. Soldavini, J.; Ammerman, A.S. Serving breakfast free to all students and type of breakfast serving model are associated with participation in the School Breakfast Program. J. Acad. Nutr. Diet. 2019, 119, 1142-1149. [CrossRef] [PubMed]

53. Khan, S.; Pinckney, R.G.; Keeney, D.; Frankowski, B.; Carney, J.K. Prevalence of food insecurity and utilization of food assistance program: An exploratory survey of a Vermont middle school. J. Sch. Health 2011, 81, 15-20. [CrossRef]

54. Dykstra, H.; Davey, A.; Fisher, J.O.; Polonsky, H.; Sherman, S.; Abel, M.L.; Dale, L.C.; Foster, G.D.; Bauer, K.W. Breakfast-skipping and selecting low-nutritional-quality foods for breakfast are common among low-income urban children, regardless of food security status. J. Nutr. 2016, 146, 630-636. [CrossRef] [PubMed]

55. Rivas, D. Everyone Eats for Free-Piloting Provision 2. Sch. Bus. Aff. 1994, 61, 40-42.

56. Robinson, R.A. Food Assistance: Early Results of USDA's No-Fee School Meal Pilot Program; Report to U.S.; Government Accountability Office (GAO): Washington, DC, USA, 1994.

57. Brown, K. School Meal Programs: Experiences of the States and Districts That Eliminated Reduced-Price Fees; Report to the Chairman, Committee on Education and Labor, House of Representatives; GAO-09-584; US Government Accountability Office: Washington, DC, USA, 2009.

58. Pokorney, P.E.; Chandran, A.; Long, M.W. Impact of the Community Eligibility Provision on meal counts and participation in Pennsylvania and Maryland National School Lunch Programs. Public Health Nutr. 2019, 22, 3281-3287. [CrossRef] [PubMed]

59. Turner, L.; Guthrie, J.F.; Ralston, K. Community eligibility and other provisions for universal free meals at school: Impact on student breakfast and lunch participation in California public schools. Transl. Behav. Med. 2019, 9, 931-941. [CrossRef]

60. Tan, M.L.; Laraia, B.; Madsen, K.A.; Johnson, R.C.; Ritchie, L. Community Eligibility Provision and School Meal Participation among Student Subgroups. J. Sch. Health 2020, 90, 802-811. [CrossRef]

61. Kitchen, S.; Tanner, E.; Brown, V.; Payne, C.; Crawford, C.; Dearden, L.; Greaves, E.; Purdon, S. Evaluation of the Free School Meals Pilot; Department for Education: London, UK, 2013.

62. MacLardie, J.; Martin, C.; Murray, L.; Sewel, K. Evaluation of the Free School Meals Trial for P1 to P3 Pupils; Scottish Government Social Research: Edinburgh, UK, 2008.

63. Holford, A. Take-up of Free School Meals: Price Effects and Peer Effects. Economica 2015, 82, 976-993. [CrossRef]

64. Cohen, J.F.; Richardson, S.; Parker, E.; Catalano, P.J.; Rimm, E.B. Impact of the new US Department of Agriculture school meal standards on food selection, consumption, and waste. Am. J. Prev. Med. 2014, 46, 388-394. [CrossRef] 
65. Cohen, J.F.; Findling, M.T.G.; Rosenfeld, L.; Smith, L.; Rimm, E.B.; Hoffman, J.A. The impact of 1 year of healthier school food policies on students' diets during and outside of the school day. J. Acad. Nutr Diet. 2018, 118, 2296-2301. [CrossRef]

66. Crepinsek, M.K.; Singh, A.; Bernstein, L.S.; McLaughlin, J.E. Dietary effects of universal-free school breakfast: Findings from the evaluation of the school breakfast program pilot project. J. Am. Diet. Assoc. 2006, 106, 1796-1803. [CrossRef] [PubMed]

67. Kleinman, R.E.; Hall, S.; Green, H.; Korzec-Ramirez, D.; Patton, K.; Pagano, M.E.; Murphy, J.M. Diet, breakfast, and academic performance in children. Ann. Nutr. Metab. 2002, 46, 24-30. [CrossRef] [PubMed]

68. Adams, E.L.; Raynor, H.A.; Thornton, L.M.; Mazzeo, S.E.; Bean, M.K. Using digital imagery to quantify students' added sugar intake at lunch in Title I schools with universal free meals. Prev. Med. Rep. 2020, 20, 101253. [CrossRef]

69. Poblacion, A.; Cook, J.; Ettinger de Cuba, S.; Bovell, A.; Sheward, R.; Pasquariello, J.; Cutts, D. Can food insecurity be reduced in the United States by improving SNAP, WIC, and the community eligibility provision? World Med. Health Policy 2017, 9, 435-455. [CrossRef]

70. Ask, A.S.; Hernes, S.; Aarek, I.; Johannessen, G.; Haugen, M. Changes in dietary pattern in 15 year old adolescents following a 4 month dietary intervention with school breakfast-a pilot study. Nutr. J. 2006, 5, 33. [CrossRef] [PubMed]

71. Murphy, S.; Moore, G.; Tapper, K.; Lynch, R.; Clarke, R.; Raisanen, L.; Desousa, C.; Moore, L. Free healthy breakfasts in primary schools: A cluster randomised controlled trial of a policy intervention in Wales, UK. Public Health Nutr. 2011, 14, 219-226. [CrossRef]

72. Moore, G.F.; Murphy, S.; Chaplin, K.; Lyons, R.A.; Atkinson, M.; Moore, L. Impacts of the Primary School Free Breakfast Initiative on socio-economic inequalities in breakfast consumption among 9-11-year-old schoolchildren in Wales. Public Health Nutr. 2014, 17, 1280-1289. [CrossRef]

73. Jenkins, K.T.; Benton, D.; Tapper, K.; Murphy, S.; Moore, L. A cross-sectional observational study of the nutritional intake of UK primary school children from deprived and non-deprived backgrounds: Implications for school breakfast schemes. Int. J. Behav. Nutr. Phys. Act. 2015, 12, 86. [CrossRef]

74. Ask, A.S.; Hernes, S.; Aarek, I.; Vik, F.; Brodahl, C.; Haugen, M. Serving of free school lunch to secondary-school pupils-a pilot study with health implications. Public Health Nutr. 2010, 13, 238-244. [CrossRef]

75. IlløKken, K.E.; Bere, E.; Øverby, N.C.; Høiland, R.; Petersson, K.O.; Vik, F.N. Intervention study on school meal habits in Norwegian 10-12-year-old children. Scand. J. Public Health 2017, 45, 485-491. [CrossRef]

76. Vik, F.N.; Van Lippevelde, W.; Øverby, N.C. Free school meals as an approach to reduce health inequalities among 10-12-year-old Norwegian children. BMC Public Health 2019, 19, 951. [CrossRef]

77. Vik, F.N.; Næss, I.K.; Heslien, K.E.; Øverby, N.C. Possible effects of a free, healthy school meal on overall meal frequency among 10-12-year-olds in Norway: The School Meal Project. BMC Res. Notes 2019, 12, 382. [CrossRef]

78. Spence, S.; Matthews, J.; McSweeney, L.; Rowland, M.; Orango, P.; Adamson, A. Implementation of Universal Infant Free School Meals: A pilot study in NE England exploring the impact on Key Stage 1 pupil's dietary intake. Public Health Nutr. 2020, 1-22. [CrossRef]

79. Gatenby, L. Children's nutritional intake as part of the Eat Well Do Well scheme in Kingston-upon-Hull-a pilot study. Nutr. Bull. 2011, 36, 87-94. [CrossRef]

80. Yamaguchi, M.; Kondo, N.; Hashimoto, H. Universal school lunch programme closes a socioeconomic gap in fruit and vegetable intakes among school children in Japan. Eur. J. Public Health 2018, 28, 636-641. [CrossRef]

81. Munday, K.; Wilson, M. Implementing a health and wellbeing programme for children in early childhood: A preliminary study. Nutrients 2017, 9, 1031. [CrossRef] [PubMed]

82. Andersen, R.; Biltoft-Jensen, A.; Christensen, T.; Andersen, E.W.; Ege, M.; Thorsen, A.V.; Dalskov, S.-M.; Damsgaard, C.T.; Astrup, A.; Michaelsen, K.F. Dietary effects of introducing school meals based on the New Nordic Diet-a randomised controlled trial in Danish children. The OPUS School Meal Study. Br. J. Nutr. 2014, 111, 1967-1976. [CrossRef]

83. Sabinsky, M.S.; Toft, U.; Sommer, H.M.; Tetens, I. Effect of implementing school meals compared with packed lunches on quality of dietary intake among children aged 7-13 years. J. Nutr. Sci. 2019, 8. [CrossRef]

84. Mhurchu, C.N.; Gorton, D.; Turley, M.; Jiang, Y.; Michie, J.; Maddison, R.; Hattie, J. Effects of a free school breakfast programme on children's attendance, academic achievement and short-term hunger: Results from a stepped-wedge, cluster randomised controlled trial. J. Epidemiol. Community Health 2013, 67, 257-264. [CrossRef] [PubMed]

85. Dalma, A.; Petralias, A.; Tsiampalis, T.; Nikolakopoulos, S.; Veloudaki, A.; Kastorini, C.-M.; Papadimitriou, E.; Zota, D.; Linos, A. Effectiveness of a school food aid programme in improving household food insecurity; a cluster randomized trial. Eur. J. Public Health 2020, 30, 171-178. [CrossRef]

86. Petralias, A.; Papadimitriou, E.; Riza, E.; Karagas, M.R.; Zagouras, A.B.; Linos, A.; Team, D.P.R. The impact of a school food aid program on household food insecurity. Eur. J. Public Health 2016, 26, 290-296. [CrossRef]

87. Bartfeld, J.S.; Berger, L.; Men, F.; Chen, Y. Access to the school breakfast program is associated with higher attendance and test scores among elementary school students. J. Nutr. 2019, 149, 336-343. [CrossRef]

88. Gordanier, J.; Ozturk, O.; Williams, B.; Zhan, C. Free lunch for all! the effect of the community eligibility provision on academic outcomes. Econ. Educ. Rev. 2020, 77, 101999. [CrossRef]

89. Bartfeld, J.S.; Berger, L.; Men, F. Universal Access to Free School Meals through the Community Eligibility Provision Is Associated with Better Attendance for Low-Income Elementary School Students in Wisconsin. J. Acad. Nutr. Diet. 2020, 120, 210-218. [CrossRef] [PubMed] 
90. Laursen, R.P.; Lauritzen, L.; Ritz, C.; Dyssegaard, C.; Astrup, A.; Michaelsen, K.F.; Damsgaard, C.T. Do healthy school meals affect illness, allergies and school attendance in 8-to 11-year-old children? A cluster-randomised controlled study. Eur. J. Clin. Nutr. 2015, 69, 626-631. [CrossRef] [PubMed]

91. Popkin, B.M.; Lim-Ybanez, M. Nutrition and school achievement. Soc. Sci. Med. 1982, 16, 53-61. [CrossRef]

92. Moonie, S.; Sterling, D.A.; Figgs, L.W.; Castro, M. The relationship between school absence, academic performance, and asthma status. J. Sch. Health 2008, 78, 140-148. [CrossRef] [PubMed]

93. Singh, K.; Granville, M.; Dika, S. Mathematics and science achievement: Effects of motivation, interest, and academic engagement. J. Educ. Res. 2002, 95, 323-332. [CrossRef]

94. Smerillo, N.E.; Reynolds, A.J.; Temple, J.A.; Ou, S.-R. Chronic absence, eighth-grade achievement, and high school attainment in the Chicago Longitudinal Study. J. Sch. Psychol. 2018, 67, 163-178. [CrossRef]

95. Taylor, J.; Garnett, B.; Horton, M.A.; Farineau, G. Universal Free School Meal Programs in Vermont Show Multi-domain Benefits. J. Hunger Environ. Nutr. 2020, 15, 753-766. [CrossRef]

96. Kenney, E.L.; Barrett, J.L.; Bleich, S.N.; Ward, Z.J.; Cradock, A.L.; Gortmaker, S.L. Impact Of The Healthy, Hunger-Free Kids Act On Obesity Trends: Study examines impact of the Healthy, Hunger-Free Kids Act of 2010 on childhood obesity trends. Health Aff. 2020, 39, 1122-1129. [CrossRef]

97. Vericker, T.C.; Gearing, M.E.; Kim, S.D. Updated Nutrition Standards for School Meals Associated With Improved Weight Outcomes for Boys in Elementary School. J. Sch. Health 2019, 89, 907-915. [CrossRef] [PubMed]

98. Bartelink, N.H.; van Assema, P.; Kremers, S.P.; Savelberg, H.H.; Oosterhoff, M.; Willeboordse, M.; van Schayck, O.C.; Winkens, B.; Jansen, M.W. Can the Healthy Primary School of the Future offer perspective in the ongoing obesity epidemic in young children? A Dutch quasi-experimental study. BMJ Open 2019, 9, e030676. [CrossRef] [PubMed]

99. Bhatia, R.; Jones, P.; Reicker, Z. Competitive foods, discrimination, and participation in the National School Lunch Program. Am. J. Public Health 2011, 101, 1380-1386. [CrossRef] [PubMed]

100. Mirtcheva, D.M.; Powell, L.M. Participation in the national school lunch program: Importance of school-level and neighborhood contextual factors. J. Sch. Health 2009, 79, 485-494. [CrossRef]

101. Dahl, M.W.; Scholz, J.K. The National School Lunch Program and School Breakfast Program: Evidence on Participation and Noncompliance; Institute for Research on Poverty, University of Wisconsin-Madison: Madison, WI, USA, 2011; Available online: http://www. econ.wisc.edu/ \{\}scholz/Research/Lunch.pdf (accessed on 1 August 2020).

102. Harwell, M.; LeBeau, B. Student eligibility for a free lunch as an SES measure in education research. Educ. Res. 2010, 39, 120-131. [CrossRef]

103. Glantz, F.B.; Berg, R.; Porcari, D.; Sackoff, E.; Pazer, S. School Lunch Eligible Non-Participants: Final Report. Food and Consumer Services, USDA. 1994. Available online: https://fns-prod.azureedge.net/sites/default/files/EligNonPart-Pt1.pdf (accessed on 1 August 2020).

104. Gordon, N.; Ruffini, K. Schoolwide Free Meals and Student Discipline: Effects of the Community Eligibility Provision. Educ. Financ. Policy 2019, 1-50. [CrossRef]

105. Kho, A. Three Essays on School Reform; Vanderbilt University: Nashville, TN, USA, 2018.

106. Corcoran, S.P.; Elbel, B.; Schwartz, A.E. The effect of breakfast in the classroom on obesity and academic performance: Evidence from New York City. J. Policy Anal. Manag. 2016, 35, 509-532. [CrossRef] [PubMed]

107. Van Wye, G.; Seoh, H.; Adjoian, T.; Dowell, D. Evaluation of the New York City breakfast in the classroom program. Am. J. Public Health 2013, 103, e59-e64. [CrossRef]

108. Nolen, E.; Krey, K. The effect of universal-free school breakfast on milk consumption and nutrient intake. Food Stud. 2015, 5, 23-33. [CrossRef]

109. Davis, W.; Musaddiq, T. Estimating the effects of subsidized school meals on child health: Evidence from the community eligibility Provision in Georgia schools. SSRN 2018, 3155354. [CrossRef]

110. Rothbart, M.W.; Schwartz, A.E.; Gutierrez, E. Paying for Free Lunch: The Impact of CEP Universal Free Meals on Revenues, Spending, and Student Health; Center for Policy Research, Maxwell School, Syracuse University: Syracuse, NY, USA, 2020.

111. Holford, A.; Rabe, B. Going Universal-The Impact of Free School Lunches On Child Body Weight Outcomes; Institute for Social and Economic Research: Wivenhoe Park, UK, 2020.

112. Alex-Petersen, J.; Lundborg, P.; Rooth, D.-O. Long-Term Effects of Childhood Nutrition: Evidence from a School Lunch Reform. 2017. Available online: https://www.econstor.eu/bitstream/10419/177038/1/dp11234.pdf (accessed on 1 August 2020).

113. Rogus, S.; Guthrie, J.; Ralston, K. Characteristics of School Districts Offering Free School Meals to All Students Through the Community Eligibility Provision of the National School Lunch Program. Economic Research Service, USDA 2018. Available online: https: / /www.ers.usda.gov/webdocs/publications/89948/err-255.pdf?v=4916.5 (accessed on 1 August 2020).

114. Rabe, B.; Holford, A. Impact of the Universal Infant Free School Meal Policy. Institute for Social and Economic Research 2020. Available online: https://mk0nuffieldfounpg9ee.kinstacdn.com/wp-content/uploads/2019/11/ISER_Impact_of_the_ Universal_Infant_Free_School_Meal_policy.pdf (accessed on 1 August 2020).

115. Morelli, C.J.; Seaman, P.T. Universal versus targeted benefits: The distributional effects of free school meals. Environ. Plan. C Gov. Policy 2005, 23, 583-598. [CrossRef]

116. Sellen, P.; Huda, N.; Gibson, S.; Oliver, L. Evaluation of Universal Infant Free School Meals. January 2018. Available online: https:/ / dera.ioe.ac.uk/30988/1/UIFSM-evaluation-7.pdf (accessed on 1 August 2020). 
117. Cook, J.; Bovell, A.; Poblacion, A.; Cutts, D.B.; de Cuba, S.E.; Pasquariello, J.; Sheward, R.; Chung, R. The $\$ 1.2$ Billion Child Health Dividend. Children's HealthWatch 2017. Available online: https://childrenshealthwatch.org/wp-content/uploads/FINALWhat-If-brief-for-web.pdf (accessed on 1 August 2020).

118. Smith, T.A.; Mojduszka, E.M.; Chen, S. Did the New School Meal Standards Improve the Overall Quality of Children's Diets? Appl. Econ. Perspect. Policy 2020. [CrossRef]

119. Potamites, E.; Gordon, A. Children's Food Security and Intakes from School Meals. Mathematica Policy Research 2010. Available online: https: / / www.ers.usda.gov/webdocs/publications/84357/ccr-61.pdf?v=4130.8 (accessed on 1 August 2020). 